\title{
Distributed manufacturing: a new form of localised production?
}

\author{
Jagiit Singh Srai \\ Department of Engineering, University of Cambridge, Cambridge, UK \\ Gary Graham and Patrick Hennelly \\ University of Leeds, Leeds, UK \\ Wendy Phillips and Dharm Kapletia \\ Bristol Business School, The University of the West of England, Bristol, UK, and \\ Harri Lorentz \\ Turku School of Economics at the University of Turku, Turku, Finland
}

\begin{abstract}
Purpose - The emergence of distributed manufacturing (DM) is examined as a new form of localised production, distinct from previous manifestations of multi-domestic and indigenous production.

Design/methodology/approach - Supply network (SN) configuration and infrastructural provisioning perspectives were used to examine the literature on established localised production models as well as DM. A multiple case study was then undertaken to describe and explore the DM model further. A maximum variation sampling procedure was used to select five exemplar cases.

Findings - Three main contributions emerge from this study. First, the research uniquely brings together two bodies of literature, namely SN configuration and infrastructure provisioning to explore the DM context. Second, the research applies these theoretical lenses to establish the distinctive nature of DM across seven dimensions of analysis. Third, emerging DM design rules are identified and compared with the more established models of localised production, drawing on both literature and DM case evidence.

Practical implications - This study provides a rich SN configuration and infrastructural provisioning view on DM leading to a set of design rules for DM adoption, thus supporting practitioners in their efforts to develop viable DM implementation plans.

Originality/value - The authors contribute to the intra- and inter-organisational requirements for the emerging DM context by providing new perspectives through the combined lenses of SN configuration and infrastructural provisioning approaches.
\end{abstract}

Keywords Distributed manufacturing, Digitalisation, Advanced manufacturing technologies

Paper type Research paper

\section{Introduction}

Distributed manufacturing (DM) can be understood as: "technology, systems and strategies that change the economics and organisation of manufacturing, particularly with regard to location and scale". (Durach et al., 2017). Manufacturing components in different physical locations and then managing the supply chain to bring them together for final assembly of a

(C) Jagjit Singh Srai, Gary Graham, Patrick Hennelly, Wendy Phillips, Dharm Kapletia and Harri Lorentz. Published by Emerald Publishing Limited. This article is published under the Creative Commons Attribution (CCBY 4.0) licence. Anyone may reproduce, distribute, translate and create derivative works of this article (for both commercial and non-commercial purposes), subject to full attribution to the original publication and authors. The full terms of this licence may be seen at http://creativecommons. org/licences/by/4.0/legalcode

Support from the Advanced Manufacturing Supply Chain Initiative (Grant No. 35708-233529, ReMediES - Reconfiguring Medicines End-to-end Supply), and the EPSRC grants Future Continuous Manufacturing and Advanced Crystallisation (CMAC) Research Hub (Grant No. EP/P006965/1), and Redistributed Manufacturing in Healthcare Network (Grant No. EP/M017559/1) is gratefully acknowledged.

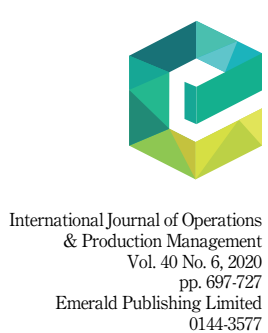

DOL 10.1108/JOPM-08-2019-3577
Received 21 August 2019 Revised 3 February 2020 Accepted 21 April 2020 
IJOPM 40,6

698

product is also considered a form of DM (Srai et al., 2016). Early-stage studies and exemplars present the potential of DM to deliver on-demand personalised consumer goods, supplement shortfalls in local demand for pharmaceuticals, produce spares in remote locations such as oil and gas rigs and enable circularity through repairs and modifications (Roscoe and Blome, 2016; Ratnayake, 2019).

Laplume et al. (2016, p. 609) suggests that DM with its associated leverage of new technologies may disrupt established supply chains and is in fact "a new localized form of production". Unlike the industrial paradigm based on economies of scale, DM could develop a business model focussed on economies of scope (Srai et al., 2016). This work investigates whether this new model can function as a different type of localised production, by contrasting DM with two other localised production models, already well established in the literature. First, the so called multi-domestic production model is a nexus of interconnected functions, operations and transactions making and delivering manufactured products (DeToni, 1992). Here local manufacturing activity largely serves as the final assembly point for bringing globally scaled resources and manufactured products together for product adaptation to the segmented tastes of the local market. Second, the indigenous production model originates naturally in a region, with individual small and medium-sized enterprises operating with a much smaller scale of capacity. Such manufacturers are embedded in the local economy, through their dependence on local resources and networks (Markusen, 1996).

For a rigorous comparison of localised production models, we adopt the configuration approach, a useful means for holistically examining dominant patterns in organisations regarding a set of multiple and interdependent characteristics (Miller, 1996). Configuration models represent multidimensional profiles of, for example, manufacturing strategies, process types or indeed production models. They often suggest that there is parsimonious set of equifinal configurations of viable strategies (cf. Bozarth and McDermott, 1998). In more detail, we use the supply network (SN) configuration concept by Srai and Gregory (2008) for holistically assessing the localised production models. The configuration approach is also driven with the idea of achieving organisational effectiveness through fit with particular environmental conditions and internal circumstances (Bozarth and McDermott, 1998; Sousa and Voss, 2008). In this vein, we additionally draw on the infrastructural provisioning perspective (Fine and Leopold, 1993), which emphasises the need for an appropriate provisioning system for localised production models in order to enable exploitation of technical and market opportunities.

Based on the aforementioned, the research question is framed as follows: How does DM compare with other localised production models from an SN configuration and infrastructural provisioning perspective? This research question allows us to explore the configurational and provisional factors underpinning sustainable DM models and how DM differs from the more established models of localised production. Therefore, in order to explore the DM model from configurational and infrastructural provisioning perspectives, a multiplecase study investigation research method was used.

\section{Research framework and the localised production models \\ 2.1 Research framework}

2.1.1 Supply network configuration perspective. The importance of the evolution of $\mathrm{SN}$ as the key element of industrial activity has been identified in many studies, linking, for example, SN structure to innovation capability (Choi and Krause, 2006), production dynamics (Kamath and Roy, 2007) and network configuration (Srai and Gregory, 2008). In this research, SN configuration provides a useful and critical lens in exploring the three different production systems. The $\mathrm{SN}$ as a unit of analysis encompasses the concept of an integrated network of key supply units, operating throughout the length of the supply chain, be they predominantly internal to a firm where there is a degree of vertical integration or largely external supply partners where there is significant outsourcing of components, parts, technology or general 
supply. Indeed, in most instances, a mixed approach is adopted across the integrated SN and represents its particular "configuration” (Srai and Gregory, 2008).

For practical purposes, the design boundaries of an SN are case-dependent and depend on the criticality of processes, materials and information flows rather than ownership or network tier position, the degree of influence any network node has on the firm and what firms can exact on any element of the network. Thus, the SN perspective of configuration considers both internal and external network members. Within strategic operations management, $\mathrm{SN}$ configuration has been shown to have a significant influence on production system capability (Srai and Gregory, 2008) and hence providesa usefulperspective for analysing and comparing localised production models.

Drawing on the literature in the field, the work by Srai and Gregory (2008) provides a useful framework for configurational analysis due to its inclusion of

(1) network structure;

(2) production process flow dynamics;

(3) product architecture; and

(4) network actor relationships. To provide clear dimensions of analysis for each of these four elements, each of these is developed further.

First, concepts of network tier structure are explored in the literature in terms of upstream and downstream complexity, levels of vertical and horizontal integration and geographical dispersion (Lambert and Cooper, 2000; Lambert and Enz, 2017). In addition to network complexity, the degrees of formalisation and centralisation have been discussed particularly in the servitisation context (Tate and Ellram, 2012).

Second, the dynamics of the replenishment process considers the push-pull decoupling point, component flows and the impact of reconfigured manufacturing processes or unit operations on product and information flows, levels of modularity, necessary/unnecessary motion, optimal sequence of production steps/subassemblies and production flexibility.

Third, the influence of product architecture (Choi and Hong, 2002) and component attributes on network configuration choices (Rezk et al., 2016). This dimension influences levels of horizontal and vertical integration within the $\mathrm{SN}$ and considers component and product stock keeping unit (SKU) complexity and variety, product life-cycle management and any service aspects of the product offering.

Fourth, the nature of transactional buyer-supplier relationships (Alinaghian et al., 2019), ranging from arm's length to ownership through vertical integration. The degree of network integration, particularly in the contemporary digital context, is highlighted at both the inbound procurement level (Srai and Lorentz, 2019) and outbound e-commerce distribution level (Lim et al., 2018). This digital perspective provides for recent infrastructural and information technology advancements that may impact emerging as well as traditional production models.

2.1.2 Infrastructural provisioning perspective. In this work, we take a system of provisioning approach to the role that infrastructure can play in supporting the development of DM. The system of provision approach takes as its units of analyses commodity-specific chains of provision, which are called "systems of provision" or "sops" (Fine and Leopold, 1993). It recognises the role played by social institutions and social-technical infrastructure, together with that of the market efforts of private organisations, in the delivery of goods and services (Brown and Robertson, 2014).

According to previous work on the "microeconomic capability" of local production systems (Lombardi, 2003), certain infrastructural provisioning attributes need to be in place, if manufacturing is to be productive and competitive. The leading works on local production systems theory of Lombardi (2003) and Lazzeretti and Storai (2003) identify the following key provisioning conditions impacting on the manufacturing organisation:

\section{Distributed manufacturing}

699 
IJOPM

40,6

\section{0}

(1) human resources;

(2) physical infrastructure (i.e. transport, energy, utilities)

(3) information infrastructure (i.e. local institutional regulation, intellectual property (IP), registration, permitting); and

(4) scientific and technological infrastructure (i.e. hardware, software). With the deployment of technology andscience to improve physical infrastructural performance, there has been recently a focus on the integration of physical, scientific and technological infrastructures together (i.e. intelligent transportation systems, smart energy, smart buildings).

We have developed the "information infrastructure" element, re-examined and re-termed it to encompass the more common term "local institutions". We emphasise that this element focusses specifically on applied information aspects such as local laws, standards, financial incentives, investment support or regulations relating to products such as consumer protection or technical standards as well as tax and other administrative requirements. This paper will focus on a refined version of the original three key provisioning elements:

(1) physical and technological infrastructure;

(2) local institutions; and

(3) human resources.

In terms of technical-physical infrastructure, evidence gleaned from many studies indicates the role played by local infrastructure (i.e. high-quality transport, energy, telecommunications) in supporting and accelerating the growth of local manufacturing (Koh et al., 2017). The role of technological infrastructure is to allow firms easier access to information sources and contact with markets, and it has been proven to have a strong positive influence on their economic effectiveness and profitability (National Infrastructural Commission, 2017). It has been recently acknowledged that government infrastructural support is instrumental for speeding up the development of new-generation digital technologies (Choi and Luo, 2019). Such developments over time may give rise to new value propositions related to manufacturing location/relocation choices. Infrastructural provisioning, for instance, is becoming central to the circular economy, in particular, the design of waste, recycling and reuse infrastructure (Kalaitz et al., 2019).

Local institutions (North, 1990) can play an active role in the creation of regional and national information hubs or platforms to support the development of collaborative and community-oriented local manufacturing networks (Anderson et al., 2002; Shubbak, 2019). The literature on local manufacturing points to the need for strong and effective regulatory and IP frameworks and local enforcement, which is cited as major issue in countries where current security, IP and legal systems are not appropriate for dealing with the rapid advancement in digital infrastructural networks (Baumers and Holweg, 2019).

Regarding human resources, the structure and size of the labour supply in a local area may have a positive influence on a manufacturing firms' location decision. Skilled labour is of great importance, especially for the development of technical innovations in manufacturing. (Oakey, 1984). With respect to advanced manufacturing, the World Economic Forum (2019) identified an urgent need in developed economies, for either "upskilling the current workforce" or "training the next generation" of skilled engineers. For instance, there is a lack of science, technology, engineering and management (STEM) education in both the US and UK workforces (Despeisse and Minshall, 2017).

2.1.3 Integration of the two perspectives. The research framework presented in Figure 1 integrates together the earlier discussed SN configuration (Srai and Gregory, 2008) and 


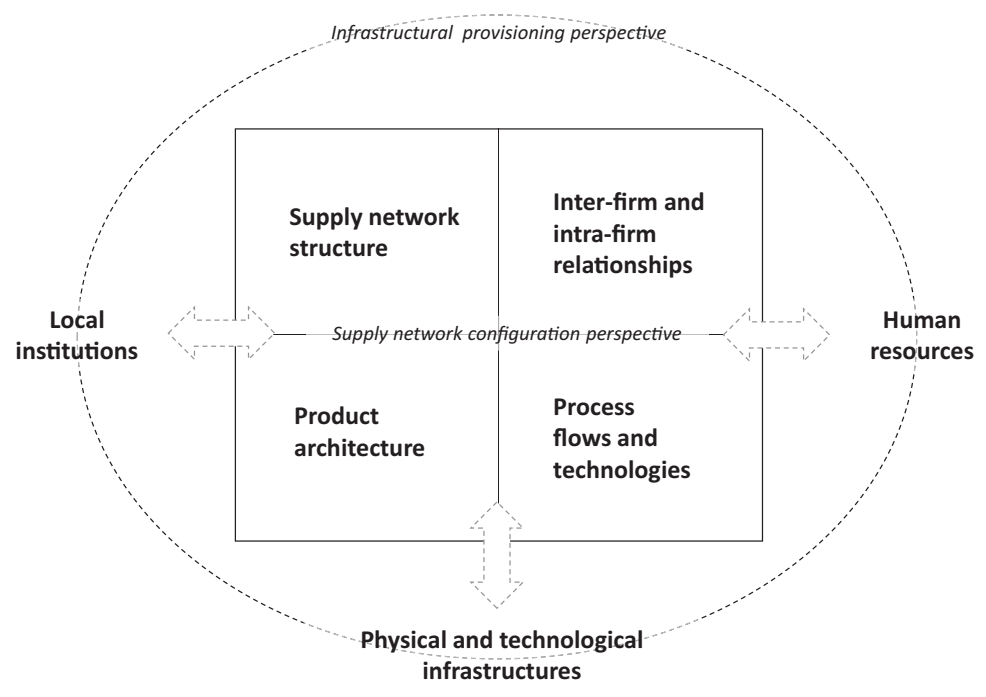

Distributed
manufacturing

701

Figure 1.

Research framework

infrastructural provisioning (Lombardi, 2003; Lazzeretti and Storai, 2003) perspectives for examining localised production models.

Essentially, we suggest that for analytical purposes, it is useful to conceptualise the SN configuration for localised production models as embedded in the infrastructural provisioning system. This embeddedness (e.g. Welch and Wilkinson, 2004) naturally implies interaction between the individual dimensions of the SN configuration and infrastructural provisioning constructs (see Figure 1). Indeed, the extant literature has discussed, for example, the influence of local institutions on manufacturing and SN structure (Sraiand Ané, 2016; Lorentz et al.,2013). The scope of this research is to examine the nature of these $\mathrm{SN}$ configuration and infrastructural provisioning dimensions independently in order to support theory building, recognising that, however, there will be interactions between dimensions that could form part of further research.

\subsection{Multi-domestic production model}

The concept of the local multi-domestic manufacturing configuration has been well established in the literature (Dunning, 1993; Gereffi et al., 2005; Mudambi, 2008). Within a global footprint, dispersed manufacturing sites were generally considered as having often limited international strategic contribution. Ferdows (1997) refers to these as "server", and in the more strategically elevated case, as "contributor" operations. In terms of the global-local trade-offs, the integration-responsiveness (IR) framework (Prahalad and Doz, 1987) set out the competing needs for scale economies through integration and local responsiveness.

In this context, the multi-domestic model was essentially considered as a loosely coupled federation, of largely independent national sub-units (Bartlett and Ghoshal, 1987) offering operational and strategic flexibility (Mascarenhas, 1982) with limited economies of scale, whilst other global or regional configurations leveraged scale investments in specialised and dedicated assets and systems that operated on a transnational basis. Others predicted that multi-domestic models might still benefit from some levels of centralised coordination; Gold (1982), for example, set out how the use of information and communication technologies may lead to flexible manufacturing systems offering both product variety and scale. In terms of the "multi-domestic" configuration option, where there is significant localisation across all stages of the value chain, they all infer a limited strategic role. This multi-domestic configuration choice is thus explained in terms 
IJOPM 40,6 of limitations on economies of scaleopportunities, resulting in a restricted headquarter coordination role with significant local autonomy.

Within the localised multi-domestic model, some consideration is given to contexts where a greater coordination role is played centrally. High levels of product modularity (McDermott et al., 2013), for example, can lead to value-adding activities to be decoupled and dispersed (Cooper et al., 1997; Ulrich, 1995). The physical characteristics of products and their implications for the flows of materials, components and knowledge that underpin the value-creation process can also impact levels of dispersion (Rezk et al., 2016). Similarly, the current dispersion of activities and tasks (Baldwin and Evenett, 2015) has also been investigated in industry studies (Alcacer and Delgado, 2016; Gray et al., 2015). In this paper, we adopt the "multi-domestic" terminology to represent the highly dispersed and localised form of the multinational, with limited international coordination, particularly in the case of products customised to the home market context and with product architectures having limited component modularity. Our definition of multidomestic production is therefore aligned with the "country-centered strategy" by Porter (1986), defined by low coordination and high dispersion, and therefore associated with the following states of the strategy implementation governing structural mechanisms (as hypothesised by Morrison and Roth, 1993): low centralisation (lack of hierarchical decision-making in the network), low formalisation (lack of use of rules and official procedures in prescribing organisational behaviour in the network) and low specialisation (lack of the extent to which management tasks are developed into centres of excellence).

The multi-domestic production model may be described in terms of an archetypal configuration as follows. The SN structure is likely to be complex, with many variety-flexible production locations near customers with regional distribution networks (Ferdows, 1997; Prahalad and Doz, 1987) and with a limited level of central coordination (Bartlett and Ghoshal, 1987). Inbound supply chains may, however, be selectively extended beyond country borders for international sources, for example, in the case of components with high value density (Rezk et al., 2016). In terms of process flows and technologies, there is likely to be only some level of standardisation of processes and technologies, as well as formalised standard operating procedures (Morrison and Roth, 1993), in order to allow for local flexibility. Codification of process knowledge may be possible, and expertise is found at the functional level and is typically geographically distributed. Enabling manufacturing technologies and IT systems vary across sites in a decentralised fashion (Bartlett and Ghoshal, 1987). Some are legacy technologies or adapted to local conditions, such as availability and serviceability (Lorentz et al., 2013). Regarding relationships, there is likely to be variety in terms of how interorganisational relationships are governed, as production unit roles vary from server to a more competent contributor type of profiles (Ferdows, 1997). Relational power towards global suppliers is likely to be relatively low due to uncoordinated procurement and spend pooling if there are no attempts towards synergies across the MNE (Trautmann et al., 2009) and limited horizontal coupling (Rezk et al.,2016). Nevertheless, power and influence on local suppliers and service providers are likely to be significant (Hong and Snell, 2013). Intra-organisational relations tends towards a devolved structure, consistent with the decentralised nature of multidomestic operations. Product architecture in the multi-domestic model is likely to be complex with broad product ranges produced in the variety-flexible sites, and the products may also be often characterised as having low value density (Rezk et al., 2016), making import substitution and alternative global strategies logistically uneconomical.

In terms of provisioning institutions, infrastructure projects are handled at sub-national level involving capacity building within provincial and municipal government targeted specific industry development zones representing long-term capital investment (UNCTAD, 2008). In terms of infrastructures as well, this type of localised production model is not very demanding, as the model may indeed be the result of constraining international trade policy measures, and it could also be considered to be able to accommodate deficiencies in logistics 
and technology infrastructures (Arvis et al., 2018) that inhibit global strategies and adoption of standardised practices and technologies across locations. The subsidiary units within the multi-domestic model seem to adapt well to location characteristics such as institutional or infrastructural constraints, for example, lack of factory services (Lorentz et al., 2013; Ashcroft and Ingham, 1979), with responsive strategies (Wei and Nguyen, 2017), and insourcedoutsourced decision-making adapted to local capabilities (Lorentz et al., 2013).

Development of highly specialised human resources is also likely to be less salient due to the replication of general types of production competencies across locations (cf. Morrison and Roth, 1993), instead of centralised excellence serving the entire network. Nevertheless, each of the sites requires a set of specialised skills, functionally based and separated, due to the selfsufficient nature of the local operations (Bartlett and Ghoshal, 1987).

\subsection{Indigenous production}

Indigenous production originates naturally in a region (e.g. leather production in Tuscany; wine production in the Côtes du Rhone; ceramics in Stoke on Trent). The indigenous manufacturing model is based on individual small enterprises operating with a much smaller scale of capacity for the production of products (i.e. food, crafts) and/or services to satisfy local demands. The manufacturer is likely to become rooted, or "embedded", in the local economy, through their specialist dependence on local skills, materials, suppliers, partner companies, research and so on (Markusen, 1996).

The theoretical analysis of indigenous production network dynamics stressed the strategic importance and part played by geographical proximity to unique factors of production (i.e. workforce skills, innovation diffusion, etc.; Belussi and Caldari, 2008). Porter (1990), for example, underlines the part played by the indigenous Italian tile and ceramic industry in the building of the domestic and export competitiveness of Tuscany. Specific assets and resources (i.e. land, labour and capital stock) are likely to play an important part in building indigenous manufacturing capacity. For instance, Saxenian (2006) points to the growth and success of the highly specialised dyeing capability of Italian clothing suppliers.

For some economists, the distinctive feature of indigenous production model is not only firm dependency on local market demand, but also the weaving of economy and society into a "communitarian" market (del Ottati, 1994). The "communitarian" approach pictures economic behaviour (in contrast to neo-classical theory) to be socio-economic and embedded in local communities, who correspondingly have shared values in jointly developing local manufacturing activity. In particular, there is a shared inward logic of development, which focusses on factors of local competitiveadvantage (i.e. local trust and cooperation, local production complementarities and local skills based on tacit knowledge), and the production system is "design intensive". In a designintensive production system, the firm is faced with the challenge of maintaining their competitive advantage through continually offering products that are different and new to that of the competition. Furthermore, indigenous production is characterised by a large number of small firms operating in specialised high-value niche markets (or industrial districts) of traditional consumer industries (i.e. shoes, apparel and furnishings) often characterised by volatile demand patterns.

The configuration of the indigenous production model, as a theoretical archetype, consists of a relatively simple $S N$ structure with a single or handful of small-scale sites within a compact geographical area, with little coordination required by owner-entrepreneurs. Both inbound and outbound supply chains are likely to be predominantly indigenous, as these naturally occurring production models draw on local materials, suppliers and partner companies (Markusen, 1996), and typically demonstrate low export propensity (Foley and Griffith, 1992). Processes and technologies are geared towards mass customisation, and there is likely to be high level of localised tacit knowledge in the product design and bespoke production processes with low level of formalisation, preventing decoupling (Rezk et al., 2016). Process design emphasises

\section{Distributed manufacturing}


IJOPM 40,6 differentiation instead of scale. As the indigenous production model draws on local specialised and unique resources and assets, relationships tend to be long-term-oriented and stable in nature, a network of indigenous supplier partners supporting the production model. Owner-managers often manage the supplier relationships in small firms, with trust and use of social factors as the fundamental elements in relationship management and governance (Morrissey and Pittaway, 2006). In terms of product architecture, the model is likely oriented towards local niche markets with a narrow and simple high-quality and branded product portfolio (Collins and Burt, 1999), although with some options for customised make-to-order (MTO) variants, aligned with the resources and capacities of the small indigenous manufacturers.

The indigenous model is provisioned by foreign trade policy institutions protecting it from multinationals and global competition, as well as by a regulatory framework and business culture which support entrepreneurialism (Ribeiro-Soriano and Galindo-Martín, 2012). Requirements for local infrastructures are likely to vary, depending on the nature of production, nevertheless it may be assumed that unique infrastructures as factors of production (Porter, 1990) may also be required for supporting indigenous production. Similarly, unique and specialised human resources are required locally with the needed tacit knowledge regarding processes and products (Belussi and Caldari, 2008).

\subsection{Distributed manufacturing}

Current research on the configuration of DM SN structure suggests mixed network complexity characterised by a shift away from large-scale global supply networks towards small-scale flexible manufacturing networks (Kapletia et al., 2019; Hennelly et al., 2019). According to Luthra et al. (2019), DM consists of a distributed network of operations serving a shared customer. An important characteristic of this new form of manufacturing is geographic dispersion and the decentralisation of operations and the supply chain close to the market (Hennelly et al., 2019; Srai et al., 2016; Rauch et al., 2015).

Yet, as this new form of DM develops, there is no consensus on what these supply networks will look like. Research by both Kumar et al. (2020) and Roscoe and Blome (2109) agrees that organisations may need to uncouple manufacturing activities and much will depend on product and process characteristics of components. Roscoe and Blome (2019) propose that organisations leverage the efficiency of centralised manufacturing and the flexibility of DM through what they term "ambidexterity capability" via the creation of different sub-units; one managing centralised production and another managing DM.

In terms of processes and technologies, an important component of a DM system is a focus on advanced technological developments (e.g. automation and robotics, additive manufacturing) that could potentially enable a much more integrated manufacturing system to be created. Various writers have also considered how small-scale manufacturing closer to the point of consumption could bring environmental benefits leading to more sustainable forms of production (e.g. Phillips, 2018; Moreno et al., 2019; Luthra et al., 2019; Kohtala, 2015; Rauch et al., 2015; DeVor et al., 2012; Kumar et al., 2016).

Much of the debate regarding processes and technologies appears to centre on the notion of "scale-out" versus "scale-up": to what degree is it economically viable to support a business model centred on flexibility, localisations and a high degree of customisation? As yet, research suggests that, in the near future, technologies such as additive manufacturing will only be used in the production of some components of the final product due to efficiency and costs (Bessière et al., 2019).

With respect to relationships, the move towards a more localised model of production supports the development of non-hierarchical relationships (Mourtzis and Doukas, 2012), allowing the consumer, or "prosumer", a greater role and participation of the local production model (Srai et al., 2016; Kohtala, 2015). Intra-firm integration of product design and 
manufacturing functions have been observed with the blurring of the traditional boundaries within the DM context (Srai et al., 2016). Mass customisation also drives integration of order placement and production (Eyers et al., 2018).

Currently, there is no agreement in terms of product architecture. Mourtzis and Doukas (2012) and Srai et al. envisage DM will give rise to greater modularity, whereas, although not entirely disagreeing with this view, Kohtala (2015) presents four different "prosumption" networks that vary in terms of consumer input and scale of production. The most extreme form of prosumption supports peer-to peer relationships which, at a small and local level, support the "personal fabrication" of goods. More conventional approaches to DM would align with "mass customisation", where the producer has control over the degree of consumer involvement and production is large-scale with a tendency towards modular or batch production. At a smaller scale, Kohtala presents the concept of "bespoke fabrication" where products can be personalised but overall control remains with the producer.

There is a growing body of literature reviewing the physical/technological infrastructural barriers and enablers for DM adoption and exploitation (Ben-Ner and Siemensen, 2017). DM does not require the same investment in supporting physical infrastructure as previous forms of advanced manufacturing. It requires a much lighter physical or what might be termed cyber-physical infrastructure, with an emerging prototype being that of a Smart City (Öberg et al., 2017; see also Kumar et al., 2016).

The human resource demands will also change with DM (Ben-Ner and Siemensen, 2017). The relatively menial jobs of assembly, retail sales, packaging, shipping, transportation are anticipated to change with the need for more: "analytical, integrative, creative, and autonomous occupations of designers, consultants, engineers, product developers and so on" (p. 21). Despeisse and Minshall (2017) suggest the need for government and industry to come together to provide easy access to training programmes for workers and students.

Despeisse and Minshall (2017) outline the need for local institutions to ensure that there is sufficient commercial protection and patent enforcement to allow firms ". . . to capture value from their local investments in DM and IP rights. As current security, IP and legal systems are not appropriate for digital networks, such cyber security concerns, if not confronted will prevent rapid DM adoption" (p. 4). Ben-Ner and Siemensen (2017) believe that whilst DM start-ups will require much less capital than in other production systems due to them not needing complex distribution chains, and through their ability to shorten design and product testing lead time, they do, however, pose substantial legal and regulatory challenges.

\section{Methods}

We undertake a multiple case study approach (Yin, 2003) for describing and exploring DM network configurations and infrastructural provisioning. Using multiple observations increases the confidence in the results being able to fully capture the phenomenon of interest, namely nature and form of the DM production model, which serves as our unit of analysis.

It is noted that case studies on SNs face major challenges in terms of, for example, defining the boundaries of the study (Halinen and Törnroos, 2005). Indeed, our analyses of the DM models also cover the broader network-oriented boundary conditions and further, include the provisioning context. Addressing this challenge, we draw on the concept of network horizon, that is, based on the perception of the decision-maker or informant regarding the relevant actors and phenomena within the visible horizon, we delimit the analysis accordingly (Halinen and Törnroos, 2005; also Carter et al., 2015).

\subsection{Data collection}

In selecting cases for the study, a purposive maximum variation sampling procedure was used for identifying information-rich cases, from which much can be learned about the

\section{Distributed manufacturing}


IJOPM 40,6

706 phenomenon (Patton, 2002). DM is not an established concept and the levels and types of adoption in industry are currently unclear. On this basis, an academic expert international panel was assembled, with 11 participants, to help identify specific gaps in DM knowledge, the major implementation issues and potential case studies to explore configuration choices design and infrastructural provisioning. Case studies were selected, covering a range of maturity levels and adoption from partial (process) through to full (production) model deployment. The five cases selected thus represent variation within roll-out or new product introduction through to first production at scale where respondents have insights on SN configuration choices and value provisioning requirements. The cases thus reflect different levels of complexity on product design, production technology and SN. Eisenhardt (1989) points out that in the context of limited cases, it is helpful to select extreme situations and polar types to better illuminate the scope of the phenomenon, therefore, cases in this study range from the simple to complex applications across product design production technology/ assembly and SN (Table 1). The set of selected cases also demonstrate a degree of variation in terms of the complexity of production technology and implementation and with the nature of firms ranging from large to small and entrepreneurial (i.e. R\&D, start-up and new organisational activity). This diversity in terms of cases (Eisenhardt, 1989) allows us to better explore the nature of the DM model through empirical observations and to support future scholarly efforts leading to greater understanding and generalisation.

A key informant/gatekeeper for each case organisation was identified by the experts at the panel. These gatekeepers identified participants who were actively involved at a project level, for introducing and scaling up DM within their organisation. Their roles were any or a combination of the following:

(1) testing the performance impact of an intervention;

(2) adjusting operational guidelines;

(3) early implementation;

(4) refining delivery strategies and materials; and

(5) scaling-up within the organisation. The selected cases are listed in Table 1 along with the involvement of multiple case respondents or informants, the used data collection methods, as well as data triangulation approaches used. A more complete description is available in Table 2.

\subsection{Data analysis}

The case study data from interviews, workshops, modelling and so on (Table 1) were used to write up within-case narratives, structured along the dimensions specified in the research framework (see Table 2, with reduced-form data; Miles and Huberman, 1994). This process of within-case analysis involved, first, the coding of the data according to the codes derived from the seven-dimension framework (Miles and Huberman, 1994) and, second, iteration in the narrative write-up phase, as a minimum of two researchers scrutinised and triangulated coding and each of the within-case narratives in terms of accuracy. In order to support the analysis and uniform coding procedures by multiple researchers, the dimensions of the research framework were defined and operationalised with literature-derived descriptions and keywords (coding structure; for operationalisations, see protocol in Appendix 1). The within-case analysis was important from the point of view of making sense of the data and the empirically observed five DM production models.

As the next step, a cross-case analysis was conducted with the help of a data display, with the five DM production models cross-tabulated with the seven dimensions. The display was populated with reduced-form data from the case narratives Miles and Huberman (1994). 


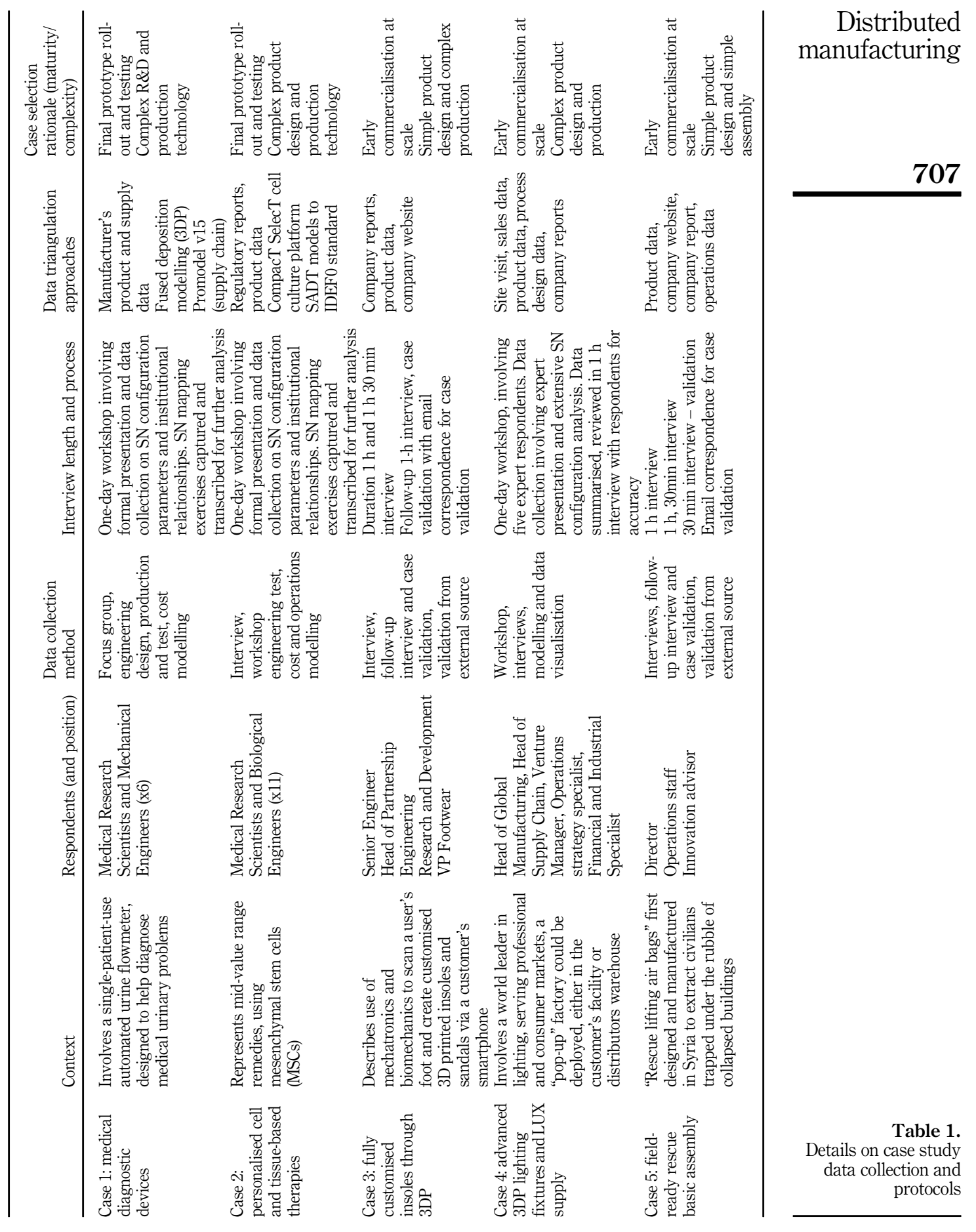




\begin{tabular}{l} 
IJOPM \\
40,6 \\
$\mathbf{7 0 8}$ \\
\hline
\end{tabular}

\begin{tabular}{|c|c|}
\hline 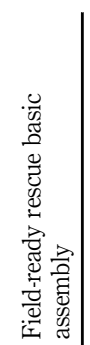 & 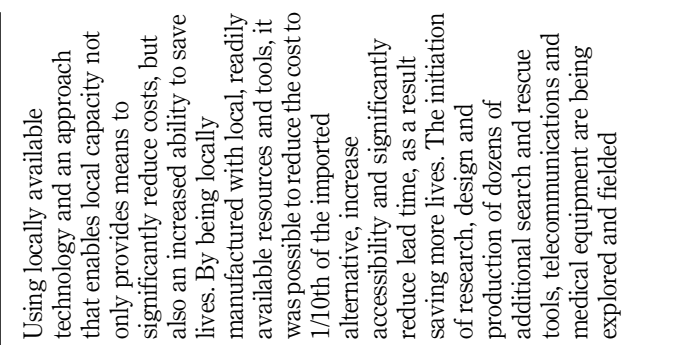 \\
\hline 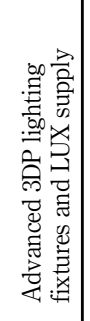 & 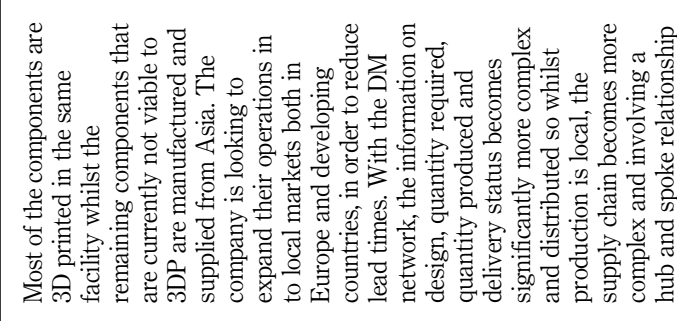 \\
\hline 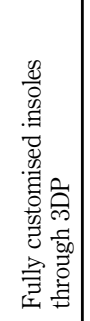 & 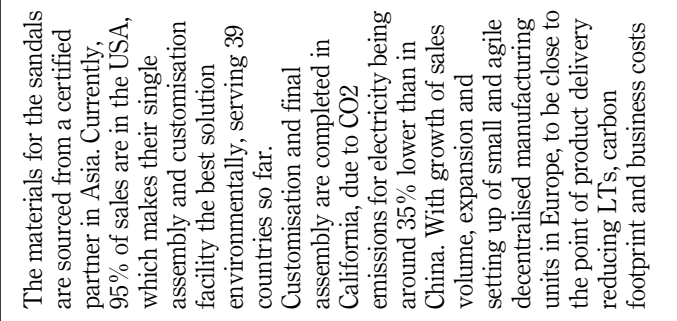 \\
\hline 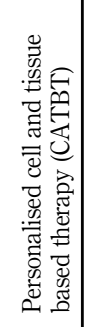 & 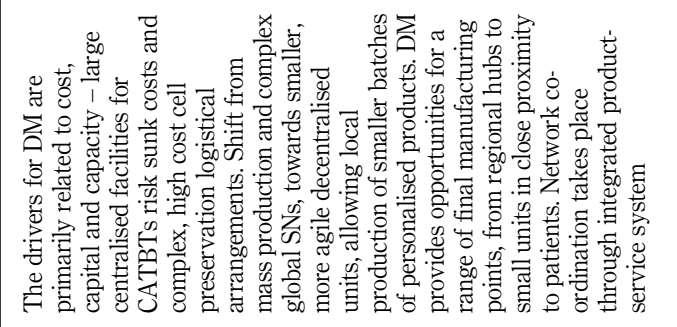 \\
\hline 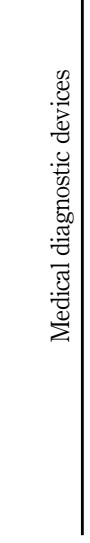 & 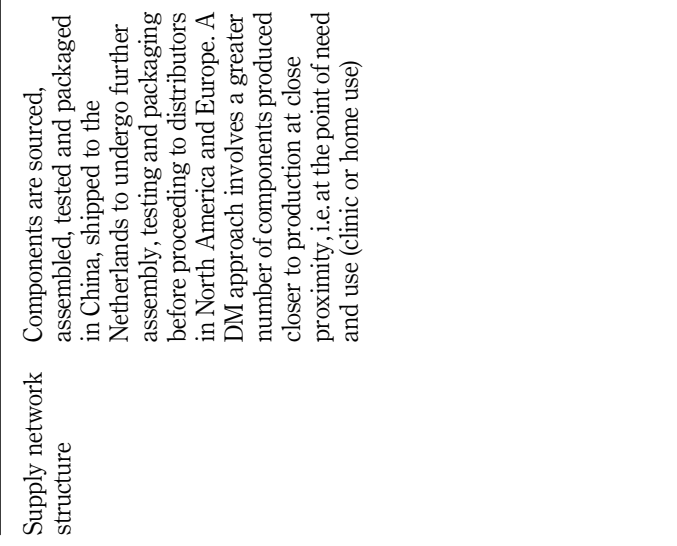 \\
\hline
\end{tabular}

Table 2.

Within-case

descriptions structured with the SN configuration coding dimensions 


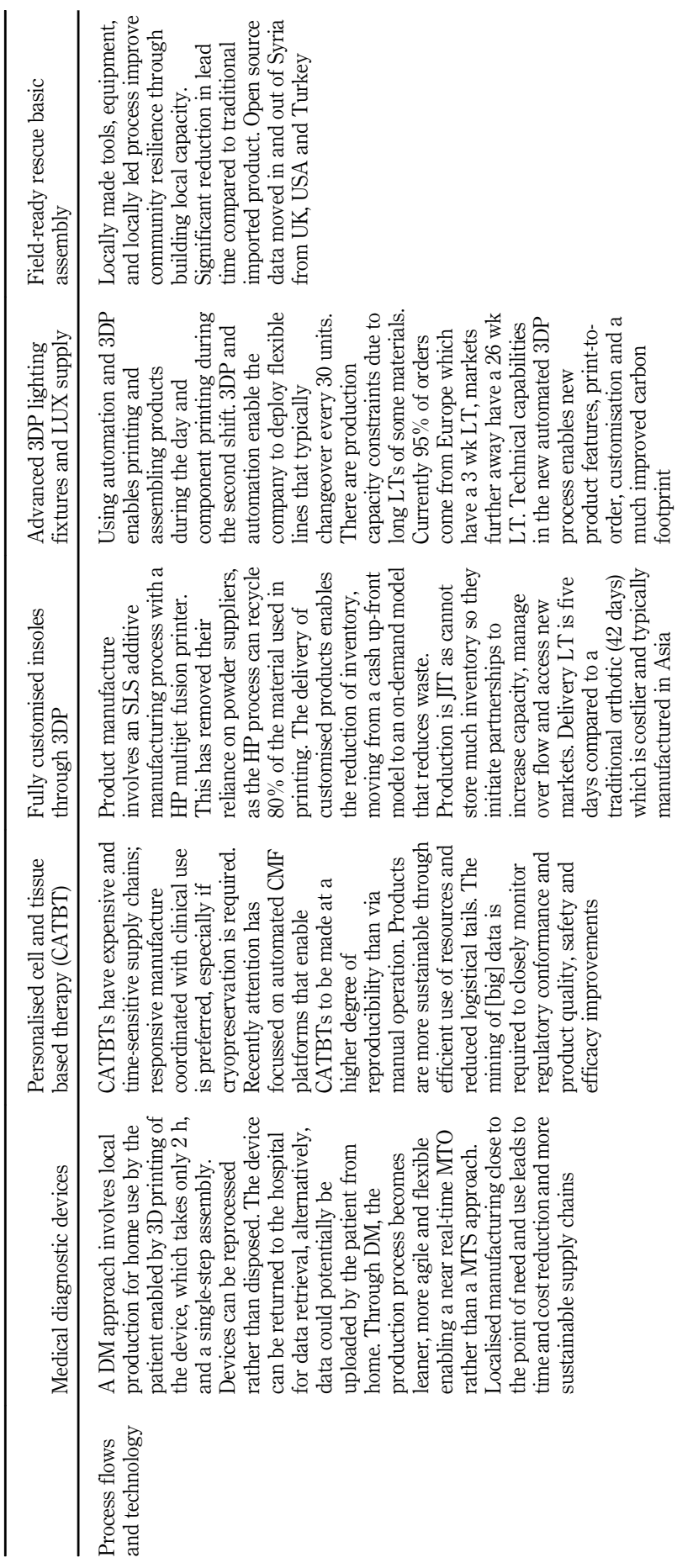




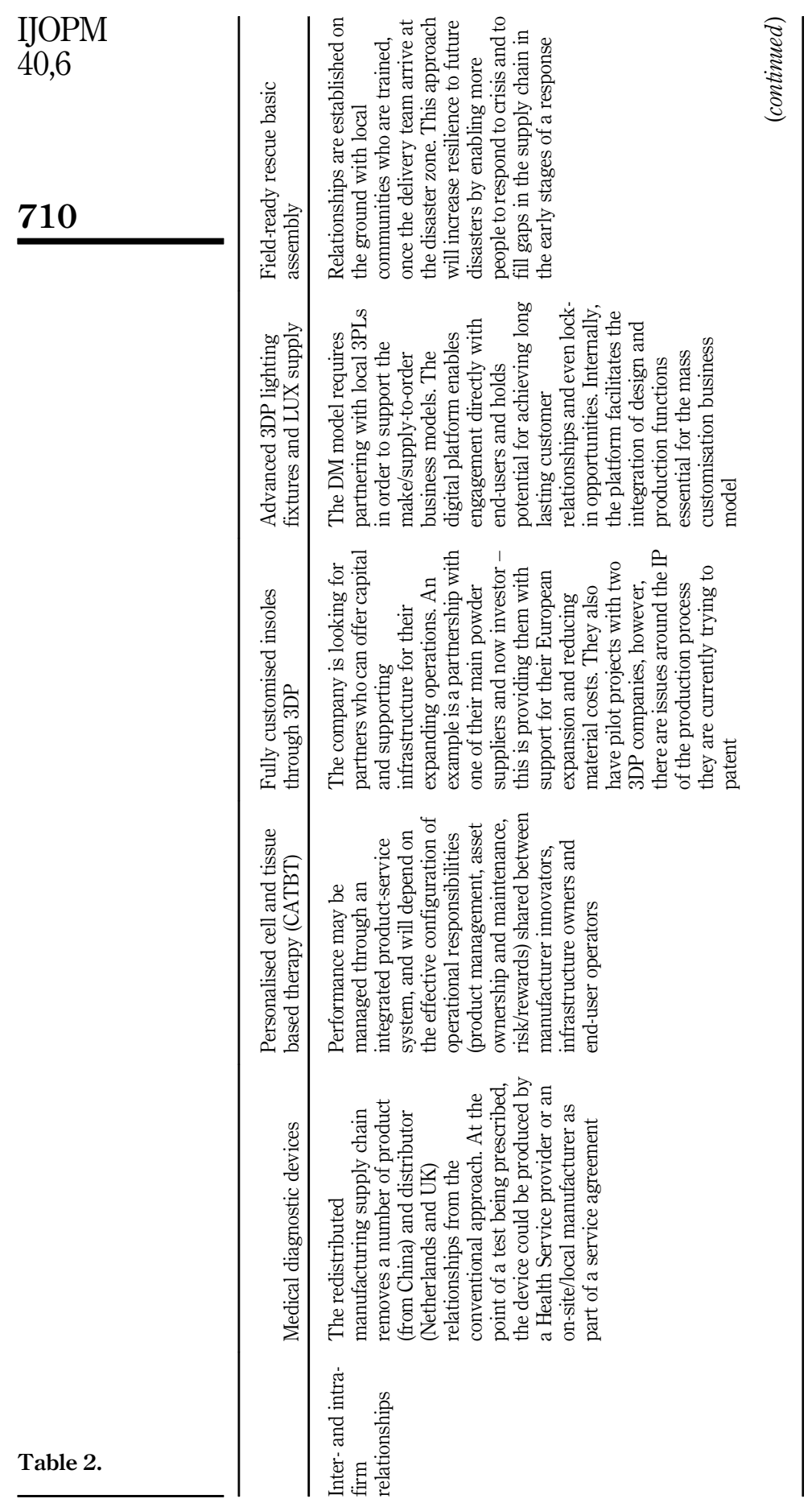




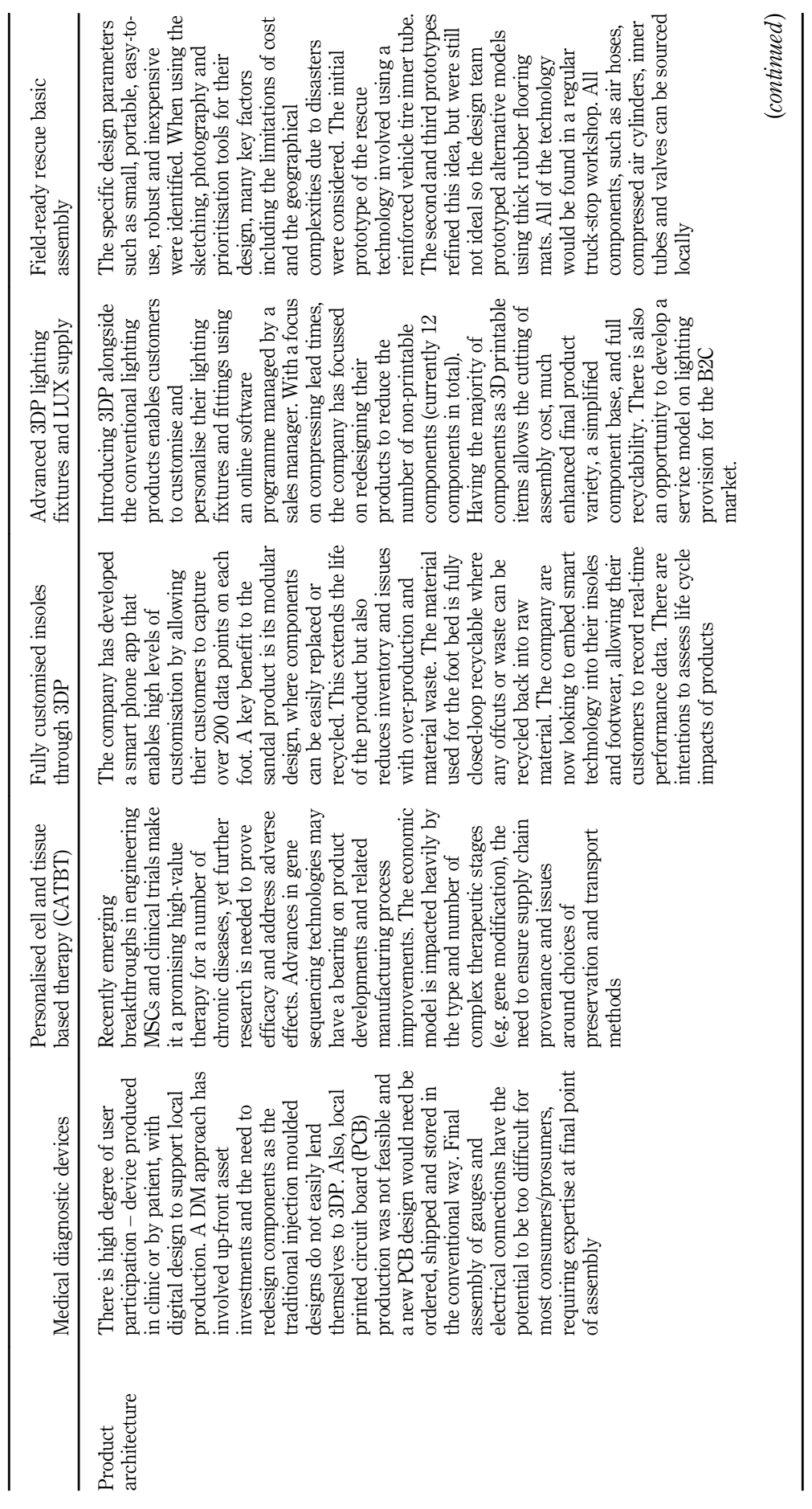

Distributed
manufacturing

711

Table 2. 


\begin{tabular}{l} 
IJOPM \\
40,6 \\
$\mathbf{7 1 2}$ \\
\hline
\end{tabular}

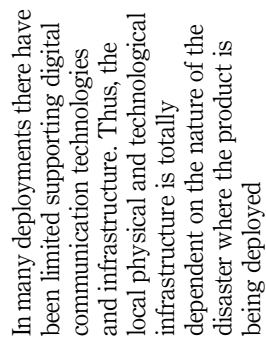

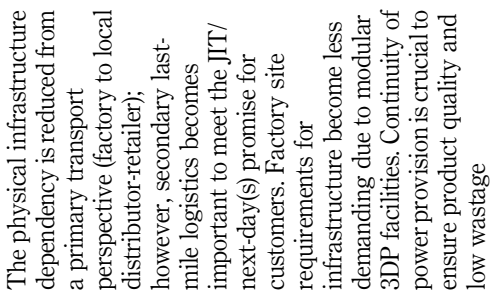

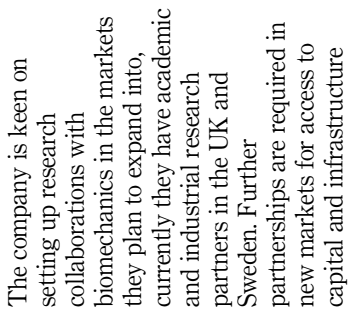

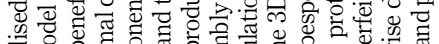

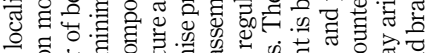

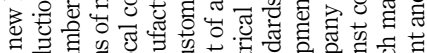

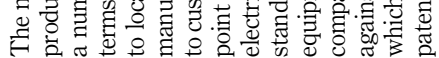

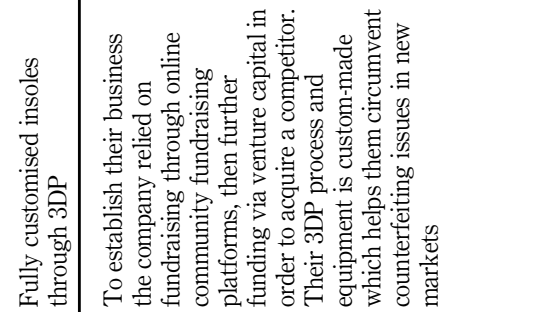




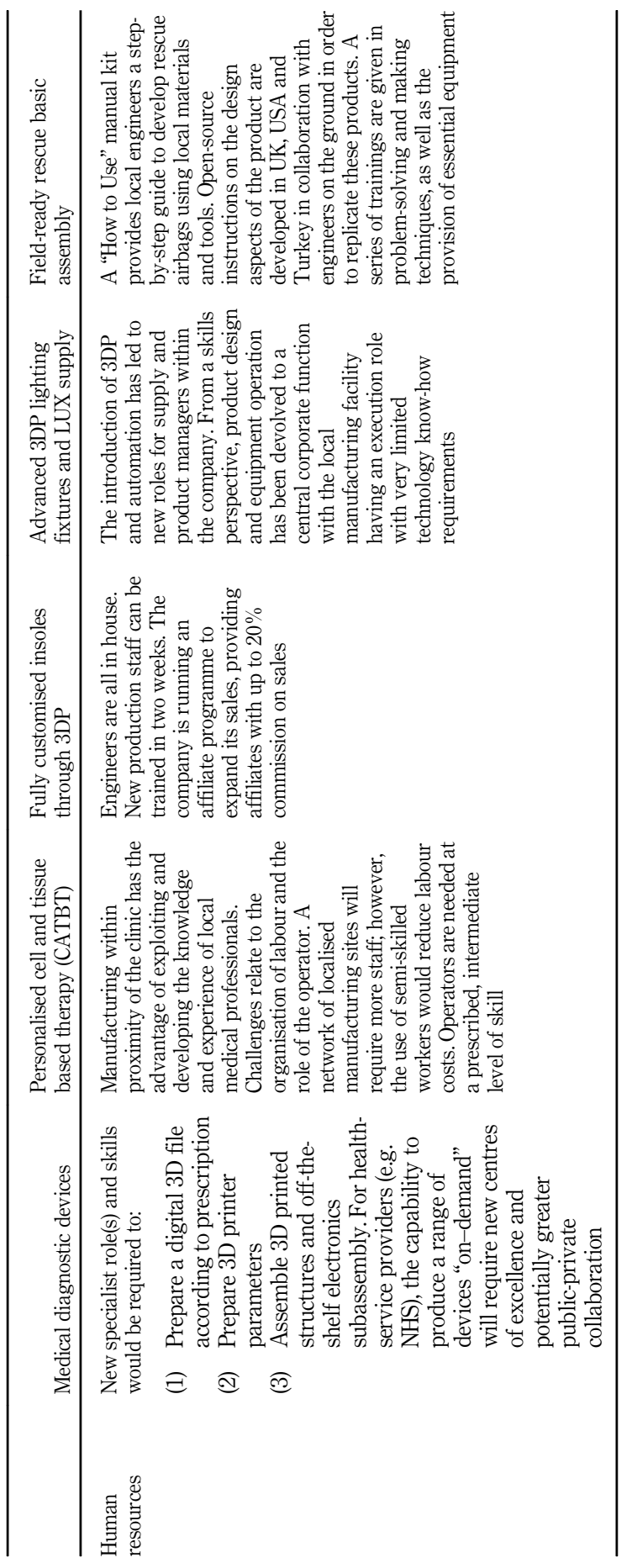

Distributed manufacturing 
IJOPM 40,6

The analysis process in this phase was again iterative as a minimum of two researchers were involved in order to ensure consistency of interpretation for data reduction and full coverage of the within-case narratives. By observing the data display, first-order thematic observations, regarding key characteristics of each of the DM production models, were made and discussed by two researchers. These first-order observations were then clustered together into second-order themes, based on thematic affinity. The outcome of this phase was a set of emergent discriminators for defining a generic DM production model. In order to qualify as a discriminator, it was necessary for a second-order theme to appear in minimum three empirically observed and analysed DM production models. The data display supported the examination of the data across the units of analysis, in addition to providing transparency and a chain of evidence regarding our conclusions.

\section{Cross-case analysis and results}

Cross-case analysis summarised in Table 3 involved analysis of the cases across the seven dimensions for coding purposes. For each case, the first-order thematic observations, as presented in Table 3, capture the salient points on both configuration and provisioning. The cross-case analysis involved further coding to identify second-order themes as set of emerging constructs. The process of moving from an a priori framework, enriched from the literature and leading to set of first-order thematic observations from the case studies provided a basis for the identification of these second-order themes (last column, Table 3). Each of the second-order themes is evidence by at least three observations across the five case studies, the relevant observation highlighted in bold and cross-referenced by a case number in the final column (Table 3).

Supply network structure: Starting with the SN configuration perspective, and observing the data display (Table 3), the dominant feature of the DM model appears to be the increased complexity of the manufacturing footprint, as production takes place in many small units or even in micro-factories at customer sites (CATBT case), close to demand (field-ready rescue case) or within short delivery lead times (diagnostic devices and lighting fixtures cases). Therefore, the outbound tier structure is typically simple in nature with relatively more direct distribution models (e.g. diagnostic devices). In contrast, there appears to be variation in terms of the inbound supply chain, as sourcing for components may be entirely localised (field-ready rescue case), the supply base may be rationalised (lighting fixtures cases) or components and raw materials sourced globally (e.g. customised insoles case, medical devices). The emerging constructs in terms of the second-order themes for SN structure in distributed manufacturing across the five case studies can be summarised as follows: close proximity to end use or consumption (as evidenced in cases $1,2,3,4$, 5; see Table 3), proliferation in manufacturing sites (cases 1, 2, 3, 4, 5), rationalised upstream SN (cases 1, 3, 4) and the critical role of the central actor in a hub-spoke network (cases 3, 4, 5).

Process flows and technologies: Based on the cross-case observations, the DM model may typically be characterised with highly modular and flexible MTO processes, facilitating late customisation or full personalisation, for example, with 3DP technology (e.g. lighting fixtures and diagnostic devices cases). Speed appears to be of essence in the DM model as significant lead time reductions have been achieved with, for example, reduced number of process steps, enabling JIT manufacturing and fast response (e.g. field-ready rescue, CATBT, customised insoles cases). Novel technologies of digitalisation are used to automate and control processes and to achieve more effective planning and scheduling, the latter with, for example, predictive analytics (e.g. lighting fixtures and CATBT cases). However, there appears to be a broad range of uses of technology, as at the other end of the range there is basic assembly with low technology characteristics (field-ready rescue case). Nevertheless, even in this case, digital technologies are used to share product design and assembly instructions. Some of the DM 


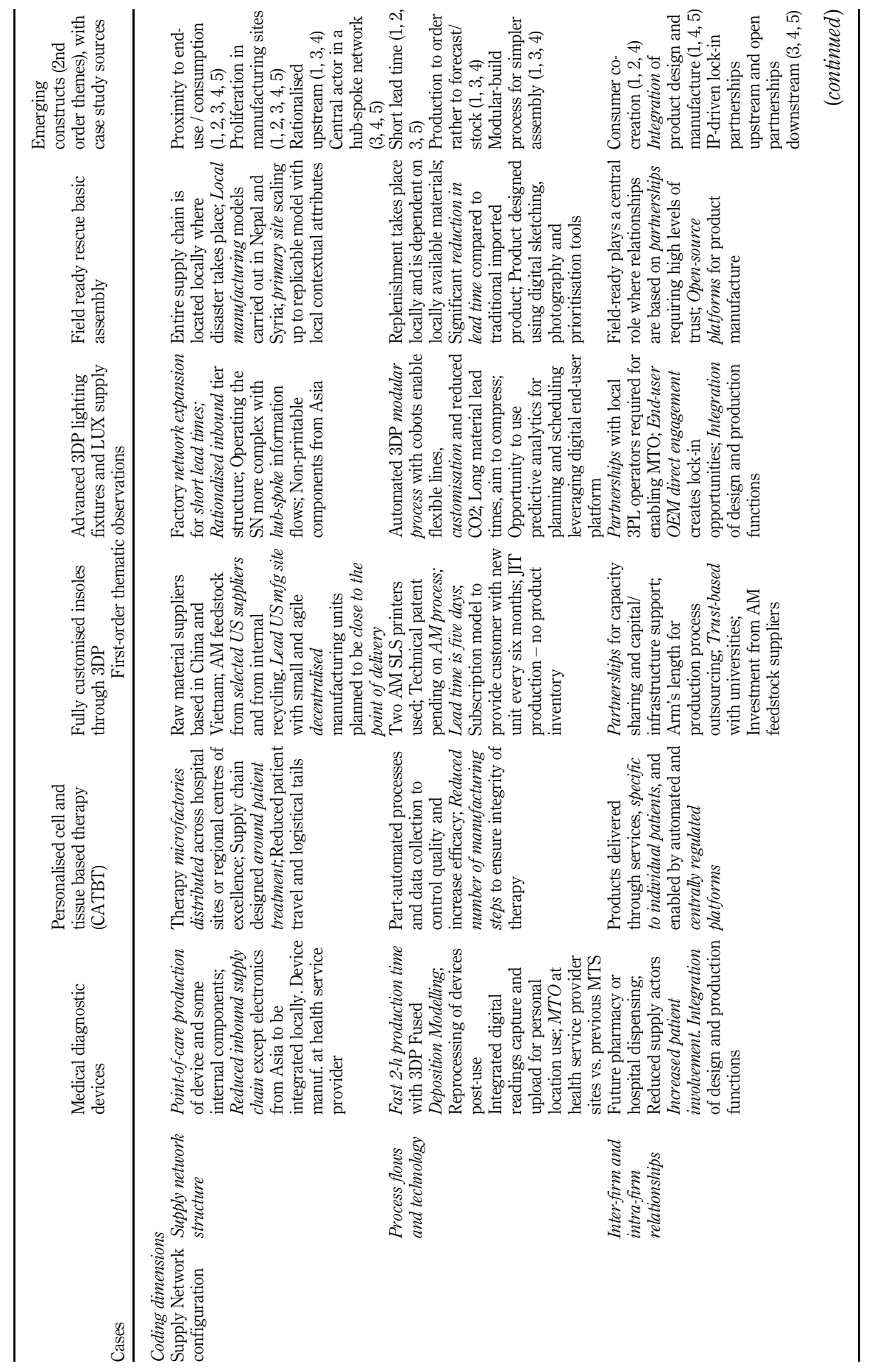

Distributed
manufacturing

715

Table 3.

Data-display for the cross-case analysis of five cases on DM 


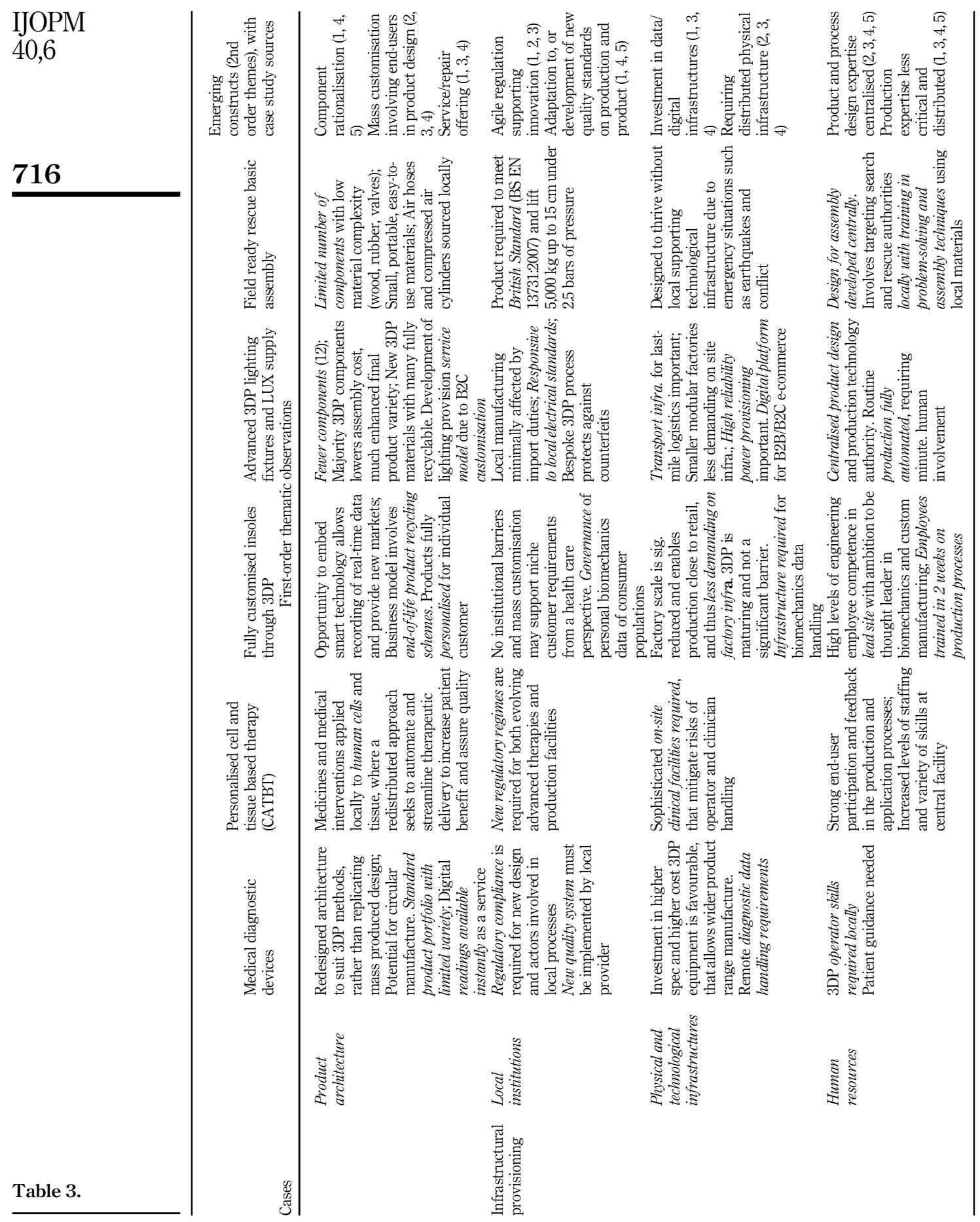


cases also suggest potential for circular economy models and more sustainable operations (e.g. diagnostic devices and lighting fixtures cases). Similarly, the emerging constructs for process flows and technology in distributed manufacturing across the five case studies can be summarised as follows: short lead time (cases 1,2,3,5), production to order rather to forecast/ stock (cases 1, 3, 4), modular-build process for simpler assembly (cases 1, 3, 4).

Inter-firm and intra-firm relationships: Across the cases, the DM model appears to imply integration, first, within the firm, in terms of product design and manufacturing (e.g. the lighting fixtures case). Second, integration may take place between firms and actors (e.g. patients in the diagnostic device case), as digital platforms are used for integrating, for example, order placement, production and distribution (e.g. CATBT and lighting fixtures cases). At the extreme, the DM model may also imply the prosumer model, in which the roles of producer and consumer overlap (e.g. the field-ready rescue case). Competitive partnership types of 3PL relationships become crucial for executing last-mile logistics (e.g. lighting fixtures case). Furthermore, the DM model may also draw on trust-based relationships with, for example, universities and the prosumer partners with open IP (customised insoles and field-ready rescue cases). Thus, we propose that the emerging constructs for inter-firm and intra-firm relationships in distributed manufacturing across the five case studies can be summarised as follows: consumer co-creation (cases 1,2,4), integration of product design and manufacture (cases 1, 4, 5), IP-driven lock-in partnerships upstream and open partnerships downstream (cases 3, 4, 5).

Product architecture: Here the cross-case analysis suggests opportunities for component reduction and therefore less work-in-process (WIP) inventory (e.g. lighting fixtures and fieldready rescue cases). The achievement of relatively simplified component base appears to be contrasted with more variety in terms of final products, and at the extreme, products are unique and customised for customer's physical characteristics (e.g. the customised insoles case). However, typically the significant increase in product variety is constrained with limited customisation options (e.g. diagnostic devices case). There appear to be also throughlife management opportunities based on use profiles. Concluding the cross-case analysis from the SN configuration perspective, we suggest that the emerging constructs for product architecture in distributed manufacturing across the five case studies can be summarised as follows: component rationalisation (cases 1,4,5), mass customisation involving end users in product design (cases 2, 3, 4), service/repair offering (cases 1, 3, 4).

Local institutions: Turning to the infrastructural provisioning perspective, the cross-case observations suggests that the DM models are flexibly adaptable to local regulation (e.g. lighting fixtures and diagnostic devices), although this is managed centrally albeit requiring local knowledge. Regulation may lag behind and needs to catch up with innovative production processes and DM facilities (e.g. CATBT case). In the cases of relatively more local inbound supply chains, the DM model appears to be resistant to the negative effects of restrictive trade policies (e.g. lighting fixtures case). The emerging constructs in terms of the second-order themes for local institutions in distributed manufacturing across the five case studies can be summarised as follows: agile regulation supporting innovation (cases 1,2,3), adaptation to, or development of, new quality standards on production and product (cases 1 , 4, 5).

Physical and technological infrastructures: In terms of infrastructural requirements of the DM model, the cross-case analysis suggests some variation, as the level of requirement appears to depend on the nature of production. High technology operations naturally require more advanced levels of supporting services and utility provision (part externally provisioned, e.g. co-location with institutional or SN partner) for product conformance (e.g. lighting fixtures and CATBT cases), whereas basic assembly may be designed to be robust enough to thrive in demanding conditions (field-ready rescue case) and enable production by consumers (diagnostic device case). In the cases where fast response and short delivery times

\section{Distributed manufacturing}


IJOPM 40,6

\section{8}

are important, the DM distribution model demands high quality infrastructure for last-mile logistics (e.g. lighting fixtures case). Thus, we propose that the emerging constructs for physical and technological infrastructures in distributed manufacturing across the five case studies can be summarised as follows: investment in data/digital infrastructures (cases 1, 3, 4), requirement for distributed physical infrastructure (cases 2, 3, 4).

Human resources: In the cases where the DM model involves high technology manufacturing or design, the cross-case analysis seems to suggest that advanced multiskill expertise may be required, co-located and centrally, whereas distributed facilities may typically require differentiated manufacturing skills although adapted to, for example, the 3DP context (e.g. lighting fixtures and customised insoles cases). The digital theme seems to permeate the DM model, as from the perspective of this dimension, digital platforms provide mechanisms for knowledge transfer to front-line production (e.g. field-ready rescue case). Furthermore, with the novel DM model, traditional staff roles may change (e.g. lighting fixtures case), and with the prosumer role evident in some cases, the users may also require increased levels of guidance and training (e.g. diagnostic devices and field-ready rescue cases). Concluding the cross-case analysis from the infrastructural provisioning perspective, we propose that the emerging constructs for human resources in distributed manufacturing across the five case studies can be summarised as follows: product and process design expertise centralised (cases 2, 3, 4,5), production expertise less critical and distributed (cases 1 , $3,4,5)$.

\section{Discussion and conclusions}

In this research, we set out to explore whether DM is a distinctive form of local production system, different from the established multi-domestic and indigenous localised production models, taking an inter- and intra-organisational network perspective. Unlike the more established multi-domestic and indigenous production models that have considered the broader production system, existing literature on the more emergent DM context has largely focussed on enabling technologies that support production at lower scale, volume/variety product flexibility and the ability to adapt to local consumer requirements. By adopting a network configuration and infrastructural provisioning perspective, the research extends current DM research.

Building on the cross-case analysis in Table 3, we now examine how DM compares with the more established multi-domestic and indigenous production models. Table 4 sets out, using the conceptual contrasting approach, how each of the three production models compares against our seven dimensions of analysis from the literature and empirical case study perspectives.

Initial analysis examines evidence from the literature, and for the more emergent DM context, cross-case empirical evidence is used to build repeat observations against the seven dimensions of analysis, providing discriminating constructs of DM when compared with other local production systems. This leads to a set of emerging constructs (through secondorder thematic coding) that provide "network"-level insights on the necessary supply network configurations and infrastructure requirements for successful DM adoption.

Three contributions have therefore emerged from this study. First, the research uniquely brings together two bodies of literature, namely SN configuration and infrastructure provisioning. This extends the work of Rezk et al. (2016) on vertical and horizontal network effects within production systems at the component and product level. Here, the research examines enabling SN configurations (that consider "vertical" SN collaborations either side of the production activity) and at the local-site level in terms of infrastructural provisioning (or "horizontal" linkages with local institutions, as well as in terms of cultural and regulatory norms). The interplay between network and infrastructural provisioning elements introduces new requirements for successful DM adoption. 


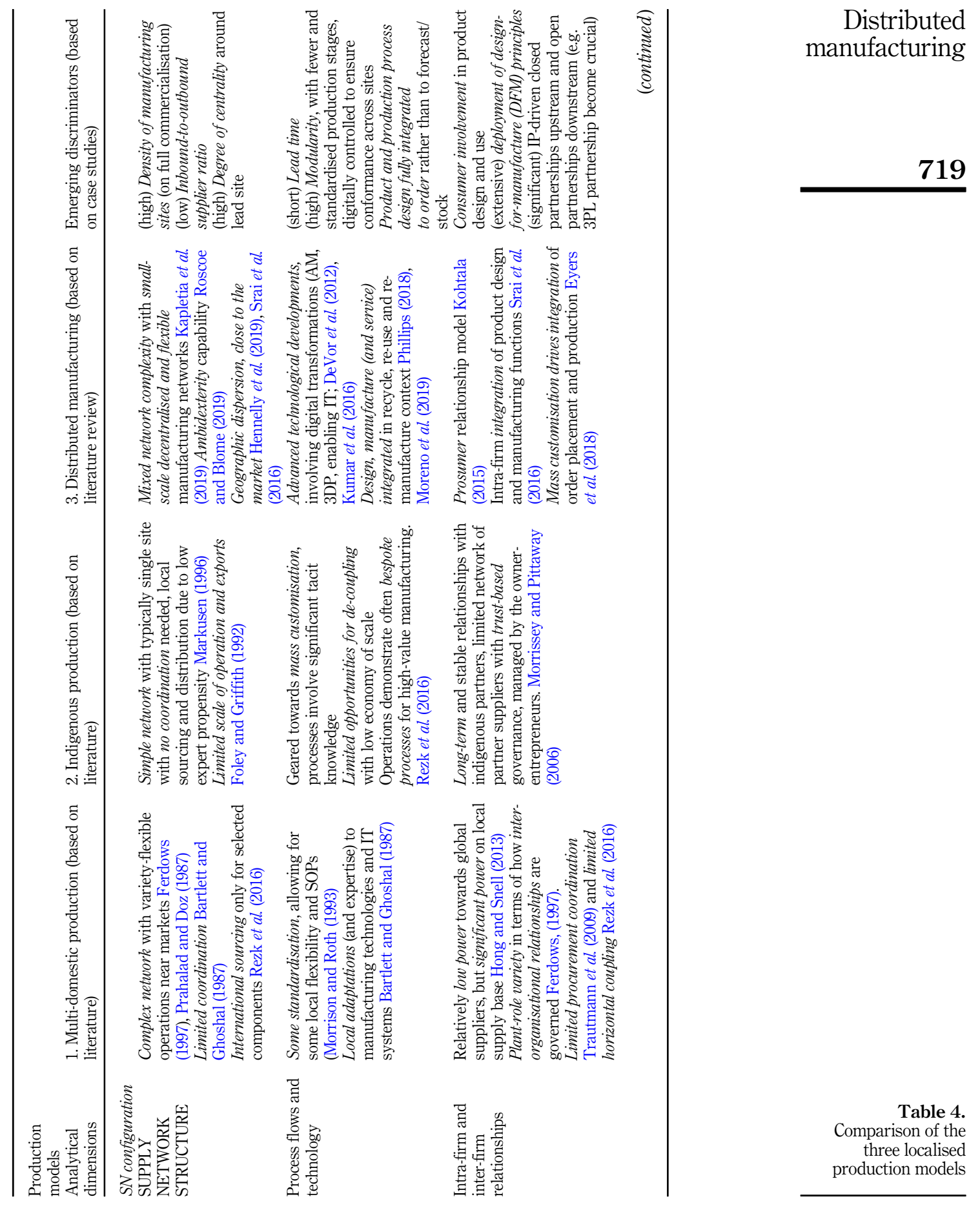




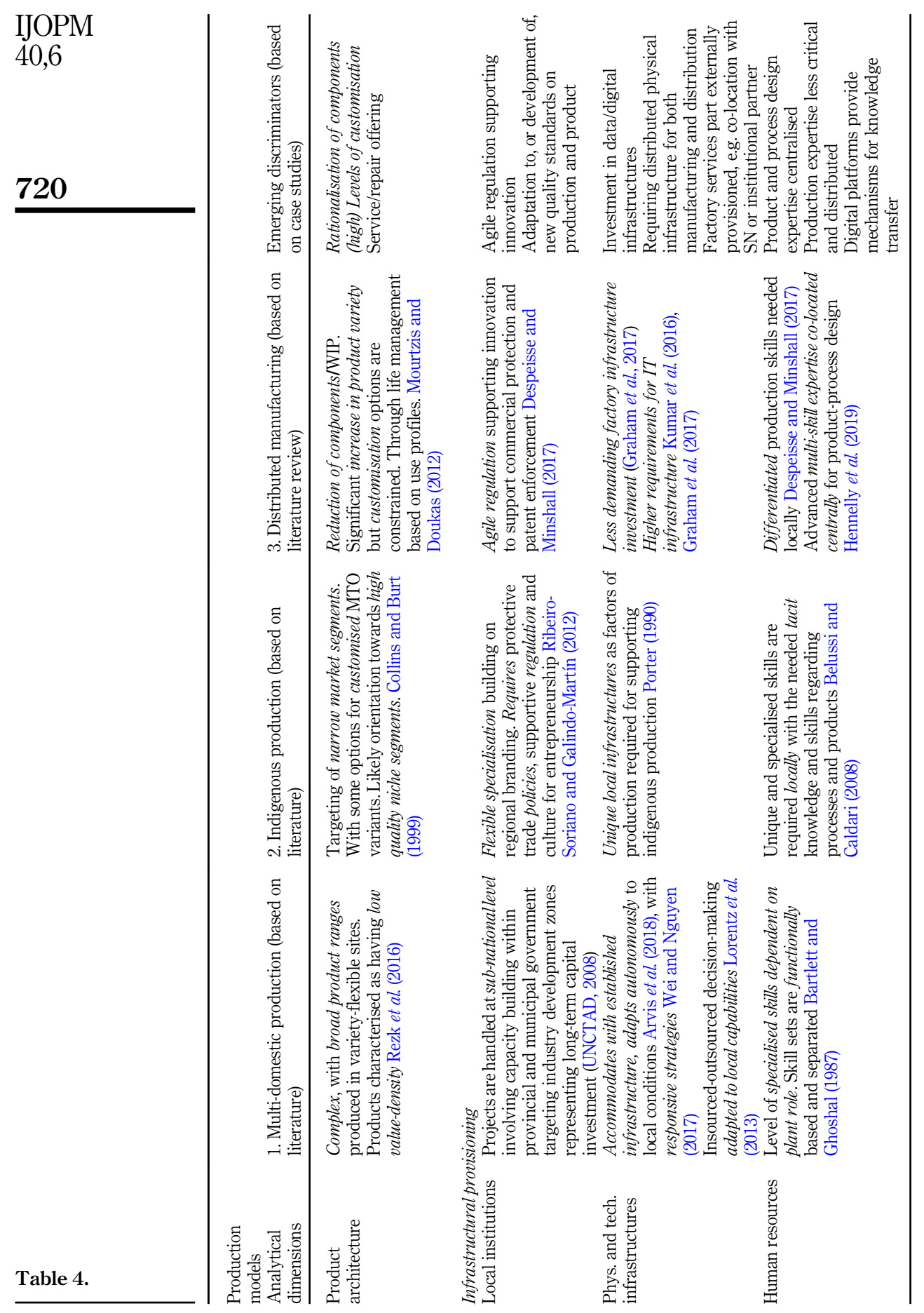


Second, the research applies the $\mathrm{SN}$ and value provisioning perspective to establish the distinctive nature of DM across the seven dimensions of analysis. These are derived from the literature and first-order case observations, identifying the critical differences that exist between these three forms of local production system. Whilst establishing the uniqueness of DM as a new form of local production system, it is particularly relevant to firms that seek to deploy DM by extending from existing forms of local production. This scenario of DM adoption, referred to as ambidexterity capability (Roscoe and Blome, 2019), findings suggest firms should consider the wider network requirements of DM beyond technology development and demand-side factors. More specifically, from a SN configuration perspective, DM is uniquely characterised by

(1) (high) density of manufacturing sites (on full commercialisation), (low) inbound-tooutbound supplier ratio and a (high) degree of centrality around the lead site requiring significant coordination;

(2) (short) production lead times, (high) modularity, with fewer and standardised production stages, digitally controlled to ensure conformance across sites, with product and production process design fully integrated supporting a production-toorder rather supply model;

(3) consumer involvement in product design and use, (extensive) deployment of design-formanufacture (DFM) principles, (significant) IP-driven closed partnerships upstream and open partnerships downstream (e.g. 3PL partnership become crucial); and

(4) rationalisation of components, with (high) levels of product customisation, integrated with a service/repair offering.

From an infrastructural provisioning perspective DM uniquely enables;

(5) agile regulation supporting innovation, adaptation to, or development of, new quality standards on production and product conformance;

(6) Investment in data/digital infrastructures, requiring distributed physical infrastructure for both manufacturing and distribution, with part externally provisioned facilities and services leveraging resources from collaborating/colocated partners and institutions; and

(7) centralised product and process design expertise centralised, production expertise less critical and distributed, with digital platforms providing mechanisms for knowledge transfer. This set of more granular observations provide rich areas for future research.

Third, emerging and discriminating DM design rules are identified drawing on both literature and DM case evidence. These second-order emerging constructs (last column Table 4) set out the requirements for DM models, defined as a set of binary dimensions required to support adoption at the local level. These extend current research on SN configuration design (Srai and Gregory, 2008), value provisioning (Saxenian, 2006) and more importantly how these two perspectives can be operationalised in combination for the implementation of DM models. Using the context of DM, we contribute to local production system theory (Saxenian, 2006) by introducing the role that infrastructural provisioning plays in the development of manufacturing activity. Previous studies have solely focussed on factors of production such as land, labour and capital in determining SN configuration (Srai and Gregory, 2008). We suggest that it is the interface between infrastructural provisioning and network configuration, which determines the development and performance of localised production models.

In conclusion, we propose that DM is indeed a new form of localised production model. By contrasting the DM model with the multi-domestic and indigenous production models, we provide discriminating network design and provisioning constructs for the emerging DM
Distributed manufacturing 
IJOPM 40,6

model. These findings contribute to the emerging theoretical knowledge on DM by providing new perspectives through the combined lenses of SN configuration and infrastructural provisioning approaches. The novel analytical framework supports future replication studies and accumulation of further evidence regarding the archetype and variety of configurations and provisioning contexts for DM.

In terms of managerial implications, our study provides a set of binary design rules on the nature and requirements of the DM model, relevant for independent or co-located facilities, demonstrating discriminating features with other forms of local production models. This provides support to practitioners in their efforts to assess and develop plans for DM and also demonstrates viable commercial opportunities for location decisions and manufacturing footprint design (Ferdows, 1997). With this improved understanding of the DM model from the SN configuration and infrastructural provisioning perspectives, future research may also seek to integrate more mature aspects of DM, together with advances in production and digitalisation technologies with intra- and inter-organisational requirements. The societal benefits of DM have been discussed in the literature, particularly in education and makerspaces, treatment at the point-of-need in healthcare and early-stage industrial development, and this research provides system design insights for both industrial and institutional players.

The authors recognise the exploratory nature of this research and the limitations of a relatively small sample of case studies, limiting generalisability, despite the case study protocols used and multiple respondents for each case.

\section{References}

Alcacer, J. and Delgado, M. (2016), "Spatial organization of firms and location choices through the value chain”, Management Science, Vol. 62 No. 11, pp. 3213-3234.

Alinaghian, L., Kim, Y. and Srai, J. (2019), "A relational embeddedness perspective on dynamic capabilities: a grounded investigation of buyer-supplier routines", Industrial Marketing Management, Vol. 85, pp. 110-125.

Andersson, U., Forsgren, M. and Holm, U. (2002), "The strategic impact of external networks: subsidiary performance and competence development in the multinational corporation", Strategic Management Journal, Vol. 23 No. 11, pp. 979-996.

Arvis, J.F., Ojala, L., Wiederer, C., Shepherd, B., Raj, A., Dairabayeva, K. and Kiiski, T. (2018), Connecting to Compete 2018: Trade Logistics in the Global Economy, World Bank, Washington, DC.

Ashcroft, B. and Ingham, K.P. (1979), "Company adaptation and the response to regional policy: a comparative analysis of MNC subsidiaries and indigenous companies", Regional Studies, Vol. 13 No. 1, pp. 25-37.

Baldwin, R.E. and Evenett, S.J. (2015), "Value creation and trade in 21st century manufacturing", Journal of Regional Science, Vol. 55 No. 1, pp. 31-50.

Bartlett, C.A. and Ghoshal, S. (1987), "Managing across borders: new strategic requirements", Sloan Management Review, Vol. 28 No. 4, pp. 7-17.

Baumers, M. and Holweg, M. (2019), "On the economics of additive manufacturing: experimental findings", Journal of Operations Management, Vol. 65 No. 8, pp. 794-809.

Belussi, F. and Caldari, K. (2008), "At the origin of the industrial district: alfred Marshall and the Cambridge school", Cambridge Journal of Economics, Vol. 33 No. 2, pp. 335-355.

Ben-Ner, A. and Siemsen, E. (2017), "Decentralization and localization of production: the organizational and economic consequences of additive manufacturing (3D printing)", California Management Review, Vol. 59 No. 2, pp. 5-23.

Bessière, D., Charnley, F., Tiwari, A. and Moreno, M.A. (2019), "A vision of re-distributed manufacturing for the UK's consumer goods industry", Production Planning \& Control, Vol. 30 No. 7 , pp. 555-567. 
Bozarth, C. and McDermott, C. (1998), "Configurations in manufacturing strategy: a review and directions for future research”, Journal of Operations Management, Vol. 16 No. 4, pp. 427-439.

Brown, A. and Robertson, M. (2014), Economic Evaluation of Systems of Infrastructure Provision: Concepts, Approaches, Methods, IBUILD/Leeds Report, University of Leeds, Leeds.

Carter, C.R., Rogers, D.S. and Choi, T.Y. (2015), "Toward the theory of the supply chain", Journal of Supply Chain Management, Vol. 51 No. 2, pp. 89-97.

Choi, T.Y. and Hong, Y. (2002), "Unveiling the structure of supply networks: case studies in Honda, acura, and Daimler Chrysler”, Journal of Operations Management, Vol. 20 No. 5, pp. 469-493.

Choi, T.Y. and Krause, D.R. (2006), "The supply base and its complexity: implications for transaction costs, risks, responsiveness, and innovation”, Journal of Operations Management, Vol. 24 No. 5, pp. 637-652.

Choi, T.M. and Luo, S. (2019), "Data quality challenges for sustainable fashion supply chain operations in emerging markets: roles of blockchain, government sponsors and environment taxes", Transportation Research Part E: Logistics and Transportation Review, Vol. 131, pp. 139-152.

Collins, A. and Burt, S. (1999), "Dependency in manufacturer-retailer relationships: the potential implications of retail internationalisation for indigenous food manufacturers", Journal of Marketing Management, Vol. 15 No. 7, pp. 673-693.

Cooper, M.C., Lambert, D.M. and Pagh, J.D. (1997), "Supply chain management: more than a new name for logistics”, The International Journal of Logistics Management, Vol. 8 No. 1, pp. 1-14.

Despeisse, M. and Minshall, T. (2017), "September. Skills and education for additive manufacturing: a review of emerging issues", IFIP International Conference on Advances in Production Management Systems, Springer, Cham, pp. 289-297.

DeToni, A., Filippini, R. and Forza, C. (1992), "Manufacturing strategy in global markets: an operations management model”, International Journal of Operations \& Production Management, Vol. 12 No. 4, pp. 7-18.

DeVor, R.E., Kapoor, S.G., Cao, J. and Ehmann, K.F. (2012), "Transforming the landscape of manufacturing: distributed manufacturing based on desktop manufacturing (DM) 2", Journal of Manufacturing Science and Engineering, Vol. 134 No. 4, 041004.

Dunning, J.H. (1993), “Internationalizing Porter's diamond”, Management International Review, Vol. 33 No. 2, p. 7 .

Durach, C.F., Kurpjuweit, S. and Wagner, S.M. (2017), "The impact of additive manufacturing on supply chains”, International Journal of Physical Distribution \& Logistics Management, Vol. 47 No. 10, pp. 954-971.

Eisenhardt, K. (1989), "Building theories from case study research", Academy of Management Review, Vol. 14 No. 4, pp. 532-550.

Eyers, D., Potter, A., Gosling, J. and Naim, M. (2018), "The flexibility of industrial additive manufacturing systems", International Journal of Operations and Production Management, Vol. 38 No. 12, pp. 2313-2343.

Ferdows, K. (1997), "Making the most of foreign factories”, Harvard Business Review, Vol. 75, pp. 73-91.

Fine, B. and Leopold, E. (1993), The World of Consumption, Routledge, London.

Foley, A. and Griffith, B. (1992), "Indigenous manufacturing enterprises in a peripheral economy and the single market: the case of the Republic of Ireland", Regional Studies, Vol. 26 No. 4, pp. 375-386.

Gereffi, G., Humphrey, J. and Sturgeon, T. (2005), "The governance of global value chains”, Review of International Political Economy, Vol. 12 No. 1, pp. 78-104.

Gold, B. (1982), "CAM sets new rules for production”, Harvard Business Review, Vol. 60 No. 6 , pp. 88-94.

Graham, G., Srai, J., Hennelly, P. and Meriton, R. (2017), “The smart city production system”, in Song, H., Srinivasan, R., Sookoor, T. and Jeschke, S. (Eds), Book Chapter 26 in Smart Cities:
Distributed manufacturing 
IJOPM 40,6

\section{4}

Foundations, Principles, and Applications, John Wiley \& Sons, Chichester, West Sussex, pp. 755-771.

Gray, J.V., Siemsen, E. and Vasudeva, G. (2015), "Colocation still matters: conformance quality and the interdependence of R\&D and manufacturing in the pharmaceutical industry", Management Science, Vol. 61 No. 11, pp. 2760-2781.

Halinen, A. and Törnroos, J.A. (2005), "Using case methods in the study of contemporary business networks", Journal of Business Research, Vol. 58 No. 9, pp. 1285-1297.

Hennelly, P.A., Srai, J.S., Graham, G., Meriton, R. and Kumar, M. (2019), "Do makerspaces represent scalable production models of community-based redistributed manufacturing?", Production Planning \& Control, Vol. 30 No. 7, pp. 540-554.

Hong, J.F. and Snell, R.S. (2013), "Developing new capabilities across a supplier network through boundary crossing: a case study of a China-based MNC subsidiary and its local suppliers", Organization Studies, Vol. 34 No. 3, pp. 377-406.

Kalaitzi, D., Matopoulos, A., Bourlakis, M. and Tate, W. (2019), "Supply chains under resource pressure: strategies for improving resource efficiency and competitive advantage", International Journal of Operations \& Production Management, Vol. 39 No. 12, pp. 1323-1354.

Kamath, N.B. and Roy, R. (2007), "Capacity augmentation of a supply chain for a short lifecycle product: a system dynamics framework”, European Journal of Operational Research, Vol. 179 No. 2, pp. 334-351.

Kapletia, D., Phillips, W., Medcalf, N., Makatsoris, H., McMahon, C. and Rich, N. (2019), "Redistributed manufacturing - challenges for operations management", Production Planning \& Control, Vol. 30 No. 7, pp. 493-495.

Koh, S.L., Gunasekaran, A., Morris, J., Obayi, R. and Ebrahimi, S.M. (2017a), "Conceptualizing a circular framework of supply chain resource sustainability", International Journal of Operations \& Production Management, Vol. 37 No. 10, pp. 1520-1540.

Kohtala, C. (2015), "Addressing sustainability in research on distributed production: an integrated literature review", Journal of Cleaner Production, Vol. 106, pp. 654-668.

Kumar, M., Graham, G., Hennelly, P. and Srai, J. (2016), "How will smart city production systems transform supply chain design: a product-level investigation", International Journal of Production Research, Vol. 54 No. 23, pp. 7181-7192.

Kumar, M., Tsolakis, N., Anshul Agarwal, A. and Srai, J.S. (2020), "Developing distributed manufacturing strategies from the perspective of a product-process matrix", International Journal of Production Economics, Vol. 219, pp. 1-17.

Lambert, D.M. and Cooper, M.C. (2000), "Issues in supply chain management", Industrial Marketing Management, Vol. 29 No. 1, pp. 65-83.

Lambert, D.M. and Enz, M.G. (2017), "Issues in supply chain management: progress and potential", Industrial Marketing Management, Vol. 62, pp. 1-16.

Laplume, A.O., Petersen, B. and Pearce, J.M. (2016), "Global value chains from a 3D printing perspective”, Journal of International Business Studies, Vol. 47 No. 5, pp. 595-609.

Lazzerretti, L. and Storai, D. (2003), "An ecology based interpretation of district complexification: the Prato district evolution from 1946 to 1993”, in Belussi, F., Gottardi, G. and Rullani, E. (Eds), The Technological Evolution of Industrial Districts, Kluwer Academic Publishers, Boston, MA.

Lim, S.F.W.T. and Srai, J.S. (2018), "Examining the anatomy of last-mile distribution in e-commerce omnichannel retailing: a supply network configuration approach", International Journal of Operations and Production Management, Vol. 38 No. 9, pp. 1735-1764.

Lombardi, M. (2003), "The evolution of local production systems: the emergence of the 'invisible mind' and the evolutionary pressures towards more visible 'minds", Research Policy, Vol. 32 No. 8, pp. 1443-1462.

Lorentz, H., Kittipanya-ngam, P. and Srai, J.S. (2013), "Emerging market characteristics and supply network adjustments in internationalising food supply chains", International Journal of Production Economics, Vol. 145 No. 1, pp. 220-232. 
Luthra, S., Mangla, S.K. and Gunjan Yadav, G. (2019), "An analysis of causal relationships among challenges impeding redistributed manufacturing in emerging economies", Journal of Cleaner Production, Vol. 225, pp. 949-962.

Markusen, A. (1996), "Sticky places in slippery space: a typology of industrial districts", Economic Geography, Vol. 72 No. 3, pp. 293-313.

Mascarenhas, B. (1982), "Coping with uncertainty in international business", Journal of International Business Studies, Vol. 13 No. 2, pp. 87-98.

McDermott, G., Mudambi, R. and Parente, R. (2013), "Strategic modularity and the architecture of multinational firm”, Global Strategy Journal, Vol. 3 No. 1, pp. 1-7.

Miles, M.B. and Huberman, M. (1994), Qualitative Data Analysis: An Expanded Sourcebook, Sage, Thousand Oaks.

Miller, D. (1996), “Configurations revisited”, Strategic Management Journal, Vol. 17, pp. 505-512.

Moreno, M., Court, R., Wright, M. and Charnley, F. (2019), "Opportunities for redistributed manufacturing and digital intelligence as enablers of a circular economy", International Journal of Sustainable Engineering, Vol. 12 No. 2, pp. 77-94.

Morrison, A. and Roth, K. (1993), "Relating Porter's configuration/coordination framework to competitive strategy and structural mechanisms: analysis and implications", Journal of Management, Vol. 19 No. 4, pp. 797-818.

Morrissey, W.J. and Pittaway, L. (2006), "Buyer-supplier relationships in small firms: the use of social factors to manage relationships", International Small Business Journal, Vol. 24 No. 3, pp. 272-298.

Mourtzis, D. and Doukas, M. (2012), "Decentralized manufacturing systems review: challenges and outlook", Logistics. Research, Vol. 5, pp. 113-121.

Mudambi, R. (2008), "Location, control and innovation in knowledge-intensive industries", Journal of Economic Geography, Vol. 8 No. 5, pp. 699-725.

National Infrastructure Commission 2017 Data sharing in infrastructure - report for the national infrastructure commission (2019), available at: https:/www.nic.org.uk/publications/data-sharinginfrastructure-report-national-infrastructure-commission/ 2017 (accessed 11 January 2020).

North, D.C. (1990), Institutions, Institutional Change and Economic Performance, Cambridge University Press, Cambridge.

Oakey, R.P. (1984), "Innovation and regional growth in small high technology firms: evidence from Britain and the USA", Regional Studies, Vol. 18 No. 3, pp. 237-251.

Öberg, C., Graham, G. and Hennelly, P. (2017), "Smart cities", IMP Journal.

Ottati, G.D. (1994), "Trust, interlinking transactions and credit in the industrial district", Cambridge Journal of Economics, Vol. 18 No. 6, pp. 529-546.

Patton, M.Q. (2002), Qualitative Research and Evaluation Methods, Sage Publications, Thousand Oaks, Cal.

Phillips, W., Medcalf, N., Dalgarno, K., Makatoris, H., Sharples, S., Srai, J., Hourd, P. and Kapletia, D. (2018), Redistributed Manufacturing in Healthcare: Creating New Value through Disruptive Innovation, UWE, Bristol.

Porter, M.E. (1986), “Changing patterns of international competition”, California Management Review, Vol. 28 No. 2, pp. 9-40.

Porter, M.E. (1990), The Competitive Advantage of Nations: With a New Introduction, Free Press, Basingstoke, Hampshire.

Prahalad, C.K. and Doz, Y.L. (1987), The Multinational Mission: Balancing Local Demands and Global Vision, Simon and Schuster, New York.

Ratnayake, R.M.C. (2019), "Enabling RDM in challenging environments via additive layer manufacturing: enhancing offshore petroleum asset operations", Production Planning \& Control, Vol. 30 No. 7, pp. 522-539.
Distributed
manufacturing 
IJOPM 40,6

Rauch, E., Dallinger, M., Dallasega, P. and Matt, D.T. (2015), "Sustainability in manufacturing through distributed manufacturing systems (DMS)", Procedia CIRP, Vol. 29, pp. 544-549.

Rezk, R., Srai, J.S. and Williamson, P.J. (2016), "The impact of product attributes and emerging technologies on firms' international configuration", Journal of International Business Studies, Vol. 47 No. 5, pp. 610-618.

Ribeiro-Soriano, D. and Galindo-Martín, M.Á. (2012), "Government policies to support entrepreneurship”, Entrepreneurship \& Regional Development, Vol. 24 No. 9-10, pp. 861-864.

Roscoe, S. and Blome, C. (2016), "A framework for the adoption of redistributed manufacturing in pharmaceutical supply chains", EurOMA 2016 (23rd International Annual Conference of the European Operations Management Association), Trondheim, Jun 2016, pp. 17-22.

Roscoe, S. and Blome, C. (2019), "Understanding the emergence of redistributed manufacturing: an ambidexterity perspective”, Production Planning and Control, Vol. 30 No. 7, pp. 496-509.

Saxenian, A.L. (2006), The New Argonauts: Regional Advantage in a Global Economy, Harvard University Press, Cambridge, MA.

Shubbak, M.H. (2019), "The technological system of production and innovation: the case of photovoltaic technology in China”, Research Policy, Vol. 48 No. 4, pp. 993-1015.

Sousa, R. and Voss, C.A. (2008), "Contingency research in operations management practices", Journal of Operations Management, Vol. 26 No. 6, pp. 697-713.

Srai, J.S. and Ané, C. (2016), "Institutional and strategic operations perspectives on manufacturing reshoring", International Journal of Production Research, Vol. 54 No. 23, pp. 7193-7211.

Srai, J. and Gregory, M. (2008), "A supply network configuration perspective on international supply chain development", International Journal of Operations \& Production Management, Vol. 28 No. 5, pp. 386-411.

Srai, J.S. and Lorentz, H. (2019), "Developing design principles for the digitalisation of purchasing and supply management”, Journal of Purchasing and Supply Management, Vol. 25 No. 1, pp. 78-98.

Srai, J.S., Kumar, M., Graham, G., Phillips, W., Tooze, J., Ford, S. and Ravi, B. (2016), "Distributed manufacturing: scope, challenges and opportunities", International Journal of Production Research, Vol. 54 No. 23, pp. 6917-6935.

Tate, W.L. and Ellram, L.M. (2012), "Service supply management structure in offshore outsourcing", Journal of Supply Chain Management, Vol. 48 No. 4, pp. 8-29.

Trautmann, G., Turkulainen, V., Hartmann, E. and Bals, L. (2009), "Integration in the global sourcing organization-an information processing perspective", Journal of Supply Chain Management, Vol. 45 No. 2, pp. 57-74.

Ulrich, K. (1995), "The role of product architecture in the manufacturing firm”, Research Policy, Vol. 24 No. 3, pp. 419-440.

UNCTAD, United Nations Conference on Trade and Development (2008), World Investment Report 2008: Transnational Corporations, and the Infrastructure Challenge, UN, Geneva.

Wei, Z. and Nguyen, Q.T. (2017), "Subsidiary strategy of emerging market multinationals: a home country institutional perspective", International Business Review, Vol. 26 No. 5, pp. 1009-1021.

Welch, C. and Wilkinson, I. (2004), "The political embeddedness of international business networks", International Marketing Review, Vol. 21 No. 2, pp. 216-231.

World Economic Forum (2019), Preparing for the Future of Work in Advanced Manufacturing, available at: https://www.weforum.org/projects/preparing-for-the-future-of-work-advancedmanufacturing-industry-taskforce.

Yin, R. (2003), Case Study Research: Design and Methods, Sage Publications, London. 


\section{Further reading}

Berry, H. (2017), "Managing valuable knowledge in weak IP protection countries", Journal of International Business Studies, Vol. 48 No. 7, pp. 787-807.

Boix, R. and Galletto, V. (2009), "Innovation and industrial districts: a first approach to the measurement and determinants of the I-district effect", Regional Studies, Vol. 43 No. 9, pp. 1117-1133.

Brooks, A. (2015), "Systems of provision: fast fashion and jeans", Geoforum, Vol. 63, pp. 36-39.

Kadokawa, K. (2013), "A search for an industrial cluster in Japanese manufacturing sector: evidence from a location survey", Geojournal, Vol. 78 No. 1, pp. 85-101.

\section{Appendix \\ Interview and workshop protocol for all cases}

\begin{tabular}{|c|c|c|}
\hline & Case Dimensions & $\begin{array}{l}\text { Questions for research participants - investigating the } \\
\text { nature and form of the DM production model (unit of } \\
\text { analysis) }\end{array}$ \\
\hline \multirow[t]{4}{*}{$\begin{array}{l}\text { How are the supply networks of } \\
\text { DM models configured? }\end{array}$} & Supply network structure & $\begin{array}{l}\text { How would you describe the value chain of DM } \\
\text { product(s) from materials to final use? (Illustrate the } \\
\text { journey if possible) }\end{array}$ \\
\hline & $\begin{array}{l}\text { Process flows and } \\
\text { technology }\end{array}$ & $\begin{array}{l}\text { How would you describe the key process steps and flows } \\
\text { involved in DM, including activities of end users (if } \\
\text { relevant)? (levels of responsiveness, complexity, cost, } \\
\text { waste, etc.) }\end{array}$ \\
\hline & $\begin{array}{l}\text { Inter-firm and intra-firm } \\
\text { relationships }\end{array}$ & $\begin{array}{l}\text { How would you describe the nature of key supply } \\
\text { relationships at different stages of the value chain? } \\
\text { (Integrated, transactional, etc.) }\end{array}$ \\
\hline & Product architecture & $\begin{array}{l}\text { How would you describe the structure of DM product(s)? } \\
\text { (Components, systems, digital, mechanical-benefits and } \\
\text { limitations) }\end{array}$ \\
\hline \multirow[t]{3}{*}{$\begin{array}{l}\text { How are the DM models } \\
\text { provisioned in their given } \\
\text { contexts? }\end{array}$} & Institutions & $\begin{array}{l}\text { Who are the institutional players and secondary } \\
\text { stakeholders and how would you describe } \\
\text { responsibilities and governance in the DM system? ( } Q C \text {, } \\
\text { standards, compliance, etc.) }\end{array}$ \\
\hline & $\begin{array}{l}\text { Physical and } \\
\text { technological } \\
\text { infrastructures }\end{array}$ & $\begin{array}{l}\text { How would you describe the investments and assets } \\
\text { needed for the operation and performance of the DM } \\
\text { system? (critical, enabling, ICT, output, location decisions, } \\
\text { etc.) }\end{array}$ \\
\hline & Human resources & $\begin{array}{l}\text { What are the required human resources capabilities } \\
\text { needed for DM execution and how available are they? } \\
\text { (Skills, expertise - established or to be developed) }\end{array}$ \\
\hline
\end{tabular}

\section{Corresponding author}

Jagjit Singh Srai can be contacted at: jss46@cam.ac.uk

For instructions on how to order reprints of this article, please visit our website:

www.emeraldgrouppublishing.com/licensing/reprints.htm

Or contact us for further details: permissions@emeraldinsight.com 